\title{
Ekonomik Suçluluk Bağlamında Şirket veya Kooperatifler Hakkında Yanlış Bilgi - Verme - Suçu (TCK m.164)
}

\author{
The Crime of Giving False Information About Company or Cooperatives \\ in Context of Economic Criminality (Turkish Criminal Code Art.164)
}

\section{Can Canpolat ${ }^{*}$ (iD}

\section{öz}

Şirket veya kooperatifler hakkında yanlış bilgi - verme - suçu, Türk Ceza Kanunu’nda (TCK), malvarlığına karşı işlenen suçlar içerisinde düzenlenmiştir (m.164). Ancak yapısı itibarıyla bu suç tipinin, bireylerin malvarlığı değerlerinin korunmasından ziyade, kamu düzeninin bir parçası olan ekonomik düzenin güven içerisinde işlemesini temin etmeye hizmet ettiği söylenebilir. Nitekim maddede suçun faili olarak tanımlanan kişilerin, kamuya yaptıkları beyanlar veya şirket veya kooperatif hakkında genel kurula sundukları rapor veya önerilerde gerçeğe aykırı bilgi vermeleri, herhangi bir netice aranmaksızın ceza yaptırımıyla karşılanmıştır. Bu yönüyle söz konusu suç, ekonomik suçluluğun çekirdek alanında yer almakta olup bu durum, TCK m.164'teki düzenlemenin sistematikteki konumunu tartışılmaya muhtaç hale getirmektedir. Çalışmada bu husus, ekonomik suçlulukla ilgili açıklamalar çerçevesinde değerlendirilerek bir çözüm önerisi sunulmuştur. Bunun dişında çalışmada, suçun unsurları ve özel görünüş biçimleri, suç tanımında yer verilen kavramların mahiyeti ve suçun işlenişine ait özellikler dikkate alınarak incelenmiştir. Bu çerçevede, özellikle Türk Ticaret Kanunu’nda (TTK), Sermaye Piyasası Kanunu’nda (SPKn) ve Vergi Usul Kanunu’nda (VUK) yer verilen düzenlemelerin de ele alınmasına gayret edilmiştir.

Anahtar Kelimeler: Ekonomik Suçluluk, Beyaz Yaka Suçluluğu, Sermaye Piyasası, Ticari Şirketler, Şirket Yöneticilerinin Ceza Sorumluluğu, Vergi Kaçakçıllğ 1

\section{ABSTRACT}

The crime of giving false information about company or cooperatives is regulated in Turkish Criminal Code (TCK), within the crimes against property (Art.164). However, this crime, in terms of its nature, serves to ensure the safe operation of the economic order, which is a part of the public order, but not to protecting any property value of individuals. In fact, the perpetrator provides false information in his/ her statements to the public or in the reports or suggestions he/she submitts to the general assembly of the company or the cooperative, and this act is sanctioned without seeking any results. In this respect, this crime locates in the core area of economic criminality, and that makes the systematic position of the regulation needs to be discussed. In this work, this issue was evaluated within the framework of the explanations about economic criminality, and a solution is presented. Besides, the elements of this crime and its special appearance forms were examined in this work by taking into account general concept and characteristics of this crime. In this framework, the regulations in the Turkish Commercial Code, Capital Market Code and Tax Procedure Code are considered.

Anahtar Kelimeler: Economic Criminality, White Collar Crime, Capital Market, Trading Companies, Criminal Liability of Managers of Companies, Tax Fraud

* Dr. Öğretim Üyesi, Yalova Üniversitesi Hukuk Fakültesi, Ceza ve Ceza Muhakemesi Hukuku Anabilim Dalı

Sorumlu Yazar/Correspondence Author: Can Canpolat

E-posta/E-mail: canpolat@yalova.edu.tr 


\section{Giriş}

Şirket veya kooperatifler hakkında yanlış bilgi verme suçu, TCK'da, kişilere karşı suçların yer aldığ ikinci kısmın, malvarlığına karşı suçlar başlıklı onuncu bölümünde düzenlenmiştir. Söz konusu suç, TCK m.164'te; "Bir şirket veya kooperatifin kurucu, ortak, idareci, müdür veya temsilcileri veya yönetim veya denetim kurulu üyeleri veya tasfiye memuru sıfatını taşıyanlar, kamuya yaptıkları beyanlarda veya genel kurula sundukları raporlarda veya önerilerde ilgililerin zarara uğramasına neden olabilecek nitelikte gerçeğe aykır önemli bilgiler verecek veya verdirtecek olurlarsa..." şeklinde tanımlanmıştır.

Şirket veya kooperatifler hakkında yanlış bilgi verme, TCK’nın yürürlüğe girdiği 1 Haziran 2005’ten bu yana mevzuatımızda yer almasına rağmen, bu suçu konu edinen akademik çalışmaların sayısı yok denecek kadar azdır. Bunun önemli bir sebebi, uygulamada bu suç tipine sık rastlanmamasıdır. Nitekim tatbikatta, genellikle dolandırıcılık, bilgiye dayalı manipülasyon, muhasebe kayıtlarında ve finansal tablo ve raporlarda usulsüzlük kapsamına girmeyen durumlarda, işlenen fiilin hukuki ihtilaf kapsamında kaldığı düşünülmektedir. Bir diğer muhtemel sebep ise, bu suçun işlendiğinin tespitindeki zorluktur. Özellikle ekonomi hukukunun merkezinde yer alan şirket veya kooperatiflerin faaliyetleri kapsamında işlenmesi dolayısıyla, söz konusu suçun unsurlarının detaylıca incelenmesi, bu noktada faydalı olacaktır.

TCK m.164’ün mehazının, İsviçre Ceza Kanunu’nun 152'nci maddesi olduğu söylenebilir. Zira burada da benzer bir düzenlemeye yer verildiği görülmektedir. Nitekim maddede, "Bir ticaret şirketi, kooperatif veya ticari faaliyette bulunan bir işletmenin kurucusu, sahibi, sinırsız sorumluluğu bulunan hissedarı, yetkili temsilcisi veya yönetim kurulu üyesi, denetçisi veya tasfiye memuru olup kamuya yapılan duyurularda veya tüm hissedarlarına yahut üyelere veya başka bir şirkette yer alan kişilere sunulan raporlarda veya teklif/önerilerde, ilgili kişinin malvarlğ̆ yönünden zarar doğurabilecek tasarruflarda bulunmasina neden olabilecek derecede önemli ve yanlş̧ veya eksik bilgi veren veya bu bilginin verilmesini sağlayan kişi, üç yıla kadar hapis veya para cezası ile cezalandırılır" denilmiştir¹. İki hüküm arasındaki benzerlik nedeniyle, suç tipine ilişkin açıklamalarda, İsviçre hukuku da dikkate alınacaktır.

Çalışmada, öncelikle TCK m.164'te düzenlenen suç tipinin ekonomik suçluluk ve beyaz yaka suçluluğuyla ilişkisi ortaya konulup korunan hukuki değer nazarında suçun tasnifine ilişkin değerlendirmelere yer verilmiş, akabinde, suçun unsurları ve özel görünüş biçimleri incelenerek önem arz eden konular üzerinde duracak tarzda bir anlatım tercih edilmiştir. Bu çerçevede hukukumuzdaki ve karşılaştırmalı hukuktaki uygulamalar da nazarı itibara alınarak suçun, şirket faaliyeti kapsamında işlenmesine dair açıklamalara ağılık verilmiştir.

1 İsviçre Ceza Kanunu'nun güncel metni için bkz. www.gesetze.ch (erişim tarihi: 10.09.2020) 


\section{Suç Tipinin Ekonomik Suçluluk ve Beyaz Yaka Suçluluğuyla iliş̧kisi ve Korunan Hukuki Değer Nazarında Suçun Tasnifine İlişkin Değerlendirme}

\section{A. Ekonomik Suçlulukla ilișkisi}

\section{Genel Olarak}

XIX’uncu yüzyılda, ekonomi alanında, yalnızca kişilerin mülkiyet haklarının korunmasına yönelik yasal düzenlemelerin varlığı ile yetinilmesi, bunun dışındaki ekonomik faaliyetlerde ise "bırakınız yapsınlar (=laissez faire)” denilerek geniş bir serbesti tanınmasını öngören düşünce tarzı, XX’nci yüzyılın başlarından itibaren keskin bir değişime uğramıştır². Bu çerçevede devletler, özellikle sosyoekonomik gelişmeler karşısında, bir yandan hak ve özgürlüklerin sınırlarını belirlemek, öte yandan kişilere daha geniş bir hukuki koruma alanı sağlamak amacıyla önemli yasal düzenlemelere ihtiyaç duymuşlardır ${ }^{3}$.

Ekonomik yaşam, bireysel veya ortak ekonomik menfaatlerini geliştirmek adına münasebet içinde olan çok sayıda aktörden (gerçek/tüzel kişi) oluşur ${ }^{4}$. Ekonomiye dahil olan her aktörün, ekonomik faaliyetlerinde, faaliyet alanının tamamına ilişkin geniş ve genel bir değerlendirme yapması mümkün değildir. Bu nedenle, ekonomik faaliyetleri düzenleyen yasal bir zemin bulunması önemlidir ${ }^{5}$. Bu yasal zemini ifade eden bir kavram olarak ekonomi hukuku, ekonomik düzenin bir bütün halinde idaresini kurallara bağlayan hukuksal alandır'

Ekonominin düzenli ve istikrarlı bir yapıya sahip olması için genellikle kamu gücüne müracaat edilmeksizin, ekonomik düzene aykırılık teşkil eden davranışların, özel hukukta yer verilen yaptırımlarla karşılanması tercih edilir ${ }^{7}$. Ancak bu yaptırımlar, söz konusu amaca ulaşmak bakımından tek başlarına yeterli değildir ${ }^{8}$. Dolayısıyla, ekonomi hukukuna dahil olan bazı alanlarda, idari yaptırımlara müracaat edilmesi de mümkün kılınmıştır. Sermaye Piyasası Kurulu (SPK) tarafından çıkarılan tebliğlerle öngörülen; işlem yasağı, lisans iptali tedbirleri, bunlara örnek olarak gösterilebilir. Ekonominin, kamu düzeninin önemli bir parçası olarak kabulünün bir sonucu olarak

2 BECKER, Gary S., Crime and Punishment: An Economic Approach, Journal of Political Economy, Mar. - Apr., 1968, Vol. 76, No. 2, s. 169. Örneğin Alman ekonomi ceza hukukunun gelişimi, sanayi alanındaki gelişmelere bağlı olarak 1910 yılında, çağdaş ekonomi ceza kanunu olan İmparatorluk Potasyum Kanunu (=Das Reichkaligesetz) ile başlamıştır. (Bkz. AYGÖRMEZ, Gülsün Ayhan, Alman Ekonomi Ceza Hukukuna Giriş I, Ceza Hukuku Dergisi, S.14, Aralık 2010, s. 72.)

3 Becker, s.169, 170.

4 BUFFORD, Samuel, International Rule of Law and the Market Economy - An Outline, Southwestern Journal of Law \& Trade in The Americas, 2006, s.305.

5 Bufford, s.305.

6 CIN ŞENSOY, Şehnaz, “Ekonomik Suç Kavramı ve Ekonomik Suçların Kriminolojik Özellikleri”, Prof.Dr.Çetin Özek Armağanı, Galatasaray Üniversitesi Yayınları:32, İstanbul, 2004, s. 829.

7 Bu hususta, ekonomik suça ekonomik ceza ilkesi ile bağlantılı olan yaklaşımlara ilişkin bkz. DURSUN, Gizem, "Ekonomik Suça Ekonomik Ceza İlkesi” ve Bu Kapsamda 6362 Sayılı Sermaye Piyasası Kanunu’nda Bilgi Suistimali ve Piyasa Dolandırıcılığı Suçları İçin Öngörülen Cezaların Değerlendirilmesi, Bahçeşehir Üniversitesi Hukuk Fakültesi Dergisi, C.14, S.175-176, s.856 vd.

8 AYTEKİN İNCEOĞLU, Asuman, Bankacılık Kanunu’nda Yer Alan Suçlar, Marmara Üniversitesi SBE, Doktora Tezi, İstanbul, 2006, s.6. 
ekonomide düzen ve istikrarın devlet eliyle korunmasında, ceza hukukuna özgü yaptırımlara müracaat edilmesine de ihtiyaç duyulmuştur ${ }^{9}$. Bu çerçevede, söz konusu düzen ve istikrarı zedeleyen davranışların bazıları suç olarak kabul edilmiştir ${ }^{10}$.

\section{Bir Suçun Ekonomik Suç Olarak Kabulünde Kullanılan Ölçütler}

Ekonomik suçun homojen bir tanımını yapmak, ekonomi alanının hem ceza hukuku hem de kriminolojinin konusunu oluşturması ve bu çerçevede birçok yazar tarafından farklı bakış açıları geliştirilmesi nedeniyle oldukça zordur ${ }^{11}$. Bununla birlikte, bir suçun ekonomik suç olarak nitelendirilmesinde bazı ölçütlerden hareket edildiğini söylemek mümkündür ${ }^{12}$. Aşağıda, bu ölçütlere öz itibarıyla yer verilecektir.

\section{a. Sistematik Ölçüt ve Korunan Hukuki Değer}

Birsuçun ekonomiksuçolaraknitelendirilmesindekullanılanilkölçüt, ilgilisuçun mevzuattasistematikaçıdan düzenlendiği yerdir ${ }^{13}$. Söz gelimi, SPKn’de veya Bankacılık Kanunu’nda düzenlenen suçlar, düzenlendikleri yer dikkate alınarak ekonomik suç kapsamında değerlendirilir. Buna karşılık bazı suç tiplerinin ekonomik suç olup olmadığının belirlenmesinde, sistem kriterinin tek başına bir fonksiyonu yoktur. Bu kapsamda korunan hukuki değerden hareket eden bir yaklaşıma göre ${ }^{14}$ ekonomik suç, ekonomik faaliyetin sürdürülmesine

9 KÜÇÜKTAŞDEMİR, Özgür, Ekonomik Suçlar Bağlamında Türk Ticaret Kanunu'nda Düzenlenen Suçlar ve Cezalar, Seçkin, Ankara, 2018, s.48. Ceza hukukunda geçerli olan son çare (=ultima ratio) ilkesinin, mahiyeti itibarıyla ekonomi ceza hukuku alanında nasıl değerlendirilmesi gerektiği tartışmalıdır. Ekonomi ceza hukukunda daha çok, birey üstü bir menfaat olarak ekonomik düzen korunmaktadır. Bu çerçevede gündeme gelen soru, düzenleyici işlemler eliyle devletin, ekonomi alanındaki faaliyetleri kurallara bağlayarak sınırlandırması yerine, bazı davranışların suç olarak kabul edilerek ekonomik faaliyet alanının daha serbest bırakılmasının, daha özgürlükçü olup olmadığıdır (TIEDEMANN, Klaus/ENGELHART, Marc, Wirtschaftsstrafrecht, 5. Auflage, Vahlen, 2017, kn.228). Buna karşılık bir başka görüşe göre ise, ultima ratio ilkesinin tatbikatı, ekonomi ceza hukuku bakımından farklı bir yoruma ihtiyaç duymaz. Bu kapsamda ekonomik suçlarla mücadelede en etkin yöntem ekonomik tedbirlerdir; ceza son çare sayılmalıdır. Bu açıdan, ekonomi hukuku kapsamındaki bir kuralın ihlalini önleme amacıyla finansal kontrol mekanizmalarının işletilmesi, cezaya başvurmaktan hem daha etkili hem de ultima ratio ilkesine daha uygundur (DURSUN, Selman, Ekonomik Suçlar ve Bankacılık Suçları Bağlamında Bankacılık Düzenine Karşı İşlenen Suçlar, Seçkin, Ankara, 2005, s.49.).

10 Bu eğilim, özellikle İkinci Dünya Savaşı sonrasında daha net ve yoğun olarak gözlemlenmektedir. Ülkelerin sosyoekonomik ve siyasal gelişimleri nazarında farklı nedenlere dayanmaktaysa da ekonominin ceza hukuku eliyle korunması gerektiği hususunda ortak bir kanaat oluştuğu söylenebilir. (MAHMUTOĞLU, Fatih Selami, Ekonomik Suçlar Bağlamında Kredi Hukukundan Kaynaklanan Suç ve İdari Suçlar, Seçkin, Ankara, 2003, s. 28.)

11 BRETTEL, Hauke/SCHNEIDER, Hendrick, Wirtschaftsstrafrecht, 3. Auflage, Nomos, Baden-Baden, 2021, s.32, kn.3.

12 Aytekin-İnceoğlu'na göre bu ölçütler, fail, fiil ve hukuki yarara göre belirlenmelidir. (Aytekin-İnceoğlu, s.7 vd.)

13 Aynı yönde bkz. GÜNER, Uğur, Ekonomik Suçlar ve Ekonomi Ceza Hukukuna İlişkin Yasal Düzenlemeler, Dokuz Eylül Üniversitesi Hukuk Fakültesi Dergisi, Prof. Dr. Durmuş TEZCAN’a Armağan, C.21, Özel Sayı, 2019, s.1420. Erman’a göre, ekonomik suçun tarifinde değilse de bu tür suçların tasnifinde, ilgili suç tipinin düzenlendiği kanun nazara alınabilir. (Bkz. ERMAN, Sahir, Ticari Ceza Hukuku, C.1, Genel Kısım, 3. Bası, İstanbul, 1992, s.57.)

14 Ekonomik suç kavramının, hukuki değeri esas alarak değerlendirilmesiyle, ekonomi alanında korunan hukuki değerlerin, diğer suçlarla korunan hukuki değerlerden ayırt eden noktaların tespit edilmesinin mümkün hale geldiği hususunda bkz. Mahmutoğlu, s.33, 38. Ekonomik suçun tanımlanmasında hukuki değerden hareket edilmesi gerektiği 
yönelik, birey üstü kamusal çıkarların ihlali veya ekonomik faaliyetlerin sürdürülmesine yarayan araçların kötüye kullanılmasının önüne geçilmesi amacıyla ihdas edilen suçların genel adıdır ${ }^{15}$.

\section{b. Sosyal Zarar Ölçütü}

Bir suçun ekonomik suç olarak kabul edilmesinde kullanılan diğer bir ölçüt, sosyal zarardır. Buna göre, "mevcut ekonomik sisteme bir bütün olarak veya münferit kurumların faaliyetleri özelinde duyulan güveni ihlal eden ve dolayısıyla söz konusu ekonomik sistemin varlığını veya işleyişini tehlikeye atan suç" ekonomik suçtur ${ }^{16}$. Bu ölçüt, sosyal zararın, kanun koyucu tarafından dikkate alınmadıkça bir kıymetinin bulunmadığı ileri sürülerek eleştirilmiştir ${ }^{17}$. Bu eleştiri özü itibarıyla haklıdır. Çünkü devlet tarafından, hangi haksızlıklara ceza hukuku eliyle karşılık verileceğini belirlemede işlev gören bir araç olarak hukuk politikası çerçevesinde - suç politikası özelinde - bir suçun ihdasında sosyal zararın dikkate alınıp alınmayacağı, nihai olarak kanun koyucunun takdirindedir. Ancak aynı durumun, korunan hukuki değer bakımından da geçerli olduğunu ifade etmek gerekir.

\section{c. Ceza Muhakemesi Kurallarını Esas Alan Ölçüt}

Ekonomik suç kavramının içeriğinin tespitinde, mahkemelerin görev ve yetkilerinin düzenlendiği kanunlarda yer verilen hükümlerin de dikkate alınabileceği, diğer bir ifade ile ceza muhakemesi hukuku kurallarının bu tespitte bir fonksiyonu olabileceği de ifade edilmiştir. Örneğin Alman Mahkemelerinin Teşkilatlanmasına İlişkin Kanun'un (=Gerichtsverfassungsgesetz) 74/c maddesine göre, söz konusu düzenlemede belirtilen alanlarda işlenen, kredi dolandırıcılığı, ticari işlemlerde rüşvet gibi suçlar, bu hususta yetkilendirilen belli mahkemelerce yargılanmaktadır ${ }^{18}$. Ancak burada tanımlanan suçların bazıları, dar anlamda ekonomik faaliyete veya geniş anlamda mülkiyet hakkını ihlale yönelik değildir ${ }^{19}$. Bu bakımdan, tek başına ceza muhakemesi hukuku alanındaki düzenlemeler,

hususunda ayrıca bkz. ÖZBEK, Veli Özer, Ekonomi Ceza Hukuku, Seçkin, Ankara, 2020, s.31.

15 MEIER, Bernd Dieter, Kriminologie, 5. Auflage, C.H Beck, München, 2016, s.315, kn.7; Brettel/Schneider, s.33, kn.8. Erman'a göre ekonomik suçu (ticari suç) sadece korunan hukuki değere göre açılamak, ülke ekonomisi ile ilgili tüm alanlara giren fiilleri ekonomik suç olarak kabul etmeyi gerektireceği için ekonomik suçun tarifinde, başka kriterlere de müracaat etmek gerekir (Erman, s.58). Ekonomik suçun tarifinde, korunan hukuksal yarar kriterinin ön plana çıktığ ve bu kapsamda ekonomik suçların dar ve geniş anlamda olmak üzere iki başlık altında ele alınmasına ilişkin görüş için bkz. Dursun, Bankacılık Suçları, s.28, 37.

16 Benzer tanım için bkz. Mahmutoğlu, s.34. Ekonomik suçları sosyolojik açıdan değerlendiren bu yaklaşımın, faili esas alarak suçun değerlendirilmesinin suçun yarattığı haksızlığı ortaya koymuyor olması dolayısıla eleştiriye açık olduğu hususunda ayrıca bkz. Dursun (Gizem), s.856.

17 Meier, s.315, kn.8.

18 Bu hususta ayrıntılı bilgi için bkz. Aygörmez, s. 70.

19 Brettel/Schneider, s.33, kn.7. Hukukumuzda da bu denli kapsayıcı olmasa da benzer düzenlemelere yer verildiği görülmektedir. Örneğin SPKn m.116’ya göre, "Kanunda tanımlanan veya atıfta bulunulan suçlardan dolayı yargılama yapmaya, Hâkimler ve Savcılar Yüksek Kurulunun ihtisas mahkemesi olarak görevlendireceği asliye ceza mahkemeleri yetkilidir.” Bu düzenlemelerin en önemli yönü, hangi suçların ekonomik suç olarak kabul edilebileceğini tespitten ziyade, uzmanlaşma gereksinimine işaret etmesidir. Ancak bunun ne ölçüde temin edilebildiği tartışmalıdır. Söz konusu tartışma için bkz. TOPUZ, Veysel, Sermaye Piyasası Suçlarında Yazılı Başvuru Şartı ve Görevli ve Yetkili Mahkeme, İnönü Üniversitesi Hukuk Fakültesi Dergisi, S.10/1, 2019, s.166. 
ekonomik suçun ne anlama geldiğini belirlemede yetersizdir ${ }^{20}$.

\section{Inceleme Konusu Suç Tipine İlişkin Değerlendirme}

Ekonominin güven ve istikrarını korumak amacıyla ihdas edilen ${ }^{21}$ Sermaye Piyasası Kanunu (SPKn), Bankacılık Kanunu gibi kanunlarda düzenlenen suçların, ekonomi ceza hukukunun çekirdek alanını oluşturduğuna şüphe yoktur. Buna karşılık, ceza kanunlarında yer verilen ve malvarlığına karşı işlenen suçlar içerisinde düzenlenen ekonomik çıkar amacıyla işlenen suç tipleri, geniş anlamda ekonomi ceza hukukuna dahil edilebilirler ${ }^{22}$. Bu iki grup arasındaki temel farklılık, ekonomik çıkar amacıyla işlenen suçların aksine, ekonomi ceza hukukunun çekirdek alanına dahil olan suç tiplerinin ihdasıyla, bireylere ait malvarlığına ilişkin menfaatlerin değil, birey üstü ve münhasıran ekonominin işleyişine ilişkin menfaatlerin korunmasıdır ${ }^{23}$. Bu bakımdan kişilere ait menfaatlere yönelik cezai koruma, yalnızca yansıma niteliğindedir.

Şirket veya kooperatifler hakkında yanlış bilgi verme suçunun ihdası, Anayasamızın çeşitli maddelerinde öngörülen yükümlülüklerin yerine getirilmesine ilişkindir. Bunları şu şekilde sıralamak mümkündür ${ }^{24}$;

i. "Çalışma ve sözleşme hürriyeti” başlığı altında, "özel teşebbüsün çalışma özgürlüğünü" düzenleyen m.48/2'de yer verilen, özel teşebbüslerin milli ekonominin gereklerine ve sosyal amaçlara uygun yürümesini, güvenlik ve kararlılık içinde çalışmasını sağlayacak tedbirleri alma yükümlülüğü,

ii. Anayasa m.167'de öngörülen, para, kredi, sermaye, mal ve hizmet piyasalarının sağlıklı ve düzenli işlemelerini sağlayıcı ve geliştirici tedbirler alma ödevi,

iii. Kooperatifçiliğin gelişmesini sağlayacak tedbirlerin alınmasına dair m.171'de zikredilen yükümlülük.

Bu itibarla, mevzuatımızda böyle bir suç tipine yer verilmesi, söz konusu özgürlük alanlarının teminat altına alınmasına ve ekonomik düzenin muhafazasına matuf olup ${ }^{25}$ bu yönüyle söz konusu suçun,

20 Brettel/Schneider, s.33, kn.7.

21 Bkz. 5411 sayılı Bankacılık Kanunu m.1, 6362 sayılı Sermaye Piyasası Kanunu m.1.

22 CANPOLAT, Can, Uygulamaya Bakan Yönleriyle İşlem Temelli Piyasa Dolandırıcılığı (Manipülasyon) Suçu, in: 5. Türk-Kore Ceza Hukuku Günleri, Karşılaştırmalı Hukukta Ekonomik Suçlar Uluslararası Sempozyumu, Tebliğler, C.I, Seçkin, Ankara, 2020, s.982; Dursun, Bankacılık Suçları, s.37, 38.

23 Tiedemann/Engelhart, kn.81; Ekonomik suçların çekirdek alanında yer alan sermaye piyasası suçları yönünden bkz. DURSUN, Selman, Sermaye Piyasasında Gerçeğe Aykırılıktan Doğan Suçlar, Oniki Levha, İstanbul 2010, s.116, 117.

24 Anayasa’da seçilen ekonomik düzen ve buna bağlı olarak sevk edilen hükümlerin, ticari hayatın şekillenmesi ve korunmasının temel çerçevesini çizdiği, ekonomik hayat nedeniyle ortaya çıkan davranış kurallarının ve hukuk normlarının kaynağını teşkil ettiği hususunda bkz. Küçüiktaşdemir, s.47.

25 Günümüzde, kamunun, bir şirketin gerçek durumu hakkında yetersiz veya çok iyimser verilere dayalı olarak bilgilendirildiğine dair genel bir şüphenin mevcut olduğu, bu yönüyle anılan suç tipinin düzenlenmesinin yadsınmayacak bir öneme sahip bulunduğu hususunda bkz. DONATSCH, Andreas, Buchführung und Strafrecht Steuerstrafrecht im Zentrum, ST 3/04 (Der Schweizer Treuhänder), s.206. 
ekonomi ceza hukukunun çekirdek alanında yer aldığı söylenebilir. Bu suçla, kişilerin mülkiyet hakkının korunduğunu söylemenin, zorlama bir yorumdan öte anlamı yoktur.

\section{B. Beyaz Yaka Suçluluğu Yönünden}

Beyaz yaka suçu kavramı, ilk defa Amerikan Sosyoloji Topluluğu'nun 1939'da gerçekleştirilen Toplantısı'nda, ünlü bir kriminolog ve sosyolog olan Edwin Sutherland tarafından kullanılmıștır ${ }^{26}$. Sutherland' in tanımına göre beyaz yaka suçları; "yüksek ve itibarl bir sosyal statüye sahip kişilerin mesleklerinin icrası sırasında işledikleri suçlar" olup ${ }^{27}$ Sutherland, kurumlar ve diğer tüzel kişiler bünyesinde işlenen suçları da bu kapsamda değerlendirmektedir ${ }^{28}$. Örneğin, bilişim sistemleri aracılı̆̆ıyla malvarlığına kaşı işlenen suçlar ile rüşvet, zimmet, irtikap suçları, beyaz yakalı suçluluk çerçevesinde ele alınabilir.

Sutherland'in ortaya koyduğu bu tanım, beyaz yaka suçlarını, faili dikkate alarak açıklayan bir bakış açısını (=criminal-based) yansıtmaktadır ${ }^{29}$.

Faile göre bir tanım ortaya koyan bu yaklaşıma göre beyaz yaka suçları, genellikle mağdurla yüz yüze iken işlenen ve sokak suçları (=street crime) veya adi suçlar ${ }^{30}$ olarak anılan suç tiplerinden farklılık arz etmektedir. Zira sokak suçları, genellikle yoksul ailelerde yetişmiş, aileleri tarafından horlanmış ve hatta kullanılmış, eğitim seviyesi düşük olan işsiz kimseler tarafından işlenmektedir ${ }^{31}$. 1988 yılında yapılan bir araştırmaya göre, sokak suçlarını işleyen faillerin \%45.5’i lise mezunuyken, bu oran, beyaz yakalı suçlarda \%79.3 olarak gözlemlenmiştir. Yine beyaz yaka suçlarını işleyenlerin $\% 58.4^{\prime}$ ü sabit bir iş sahibi iken sokak suçlarını işleyen faillerde bu oran, $\% 12.7^{\prime} \mathrm{dir}^{32}$.

Beyaz yaka suçluluğuyla ilgili ortaya konulan fail odaklı yaklaşım, zaman içerisinde değişime uğramıştır. Ekonomi alanında işlenen suçlardaki çeşitlilik karşısında bu görüş, beyaz yaka suçluluğunu dar bir çerçevede kategorize etmek bakımından işlev görse de ekonomik suçluluğu diğer suçlu formlarından ayırmak konusunda yeterliliğini kaybetmiştir. Nitekim Özbek, bu çerçevede haklı

26 Sutherland’ten önce Amerika Birleşik Devletleri'nde beyazyaka suçları, 20 nci yüzyılın ilerleyen zamanlarında sanayicilerin ve siyasi liderlerin aşırılıkları ile birlikte, sosyal eleştirmenlerin büyük ilgi odağı olmuştu. Bu eleştirmenlerden bir tanesi olan Edward Alsworth Ross, sosyal ve ekonomik karşılıklı bağımlılığın, geçmiş nesiller tarafından bilinmeyen, sonucu yeni ve değişen suçluluk ve mağdurluk potansiyeli olan mutualizmin artmasına neden olduğuna vurgu yaparak, modern toplumda beyaz yaka suçu gibi yeni suç türlerinin ortaya çıkacağına işaret etmiştir. Ayrıntı için bkz. SHOVER, Neal/ HOCHSTETLER, Andy, Choosing White-Collar Crime, Cambridge University Press, 2006, s.5. Ross'un beyaz yaka suçluluğuna daha önce işaret ettiğine yönelik olarak bkz. WONG, Kam C, From White-Collar Crime to Organizational Crime: An Intellectual History, Murdoch University eLaw Journal, prg.4. çevrimiçi: http://www.austlii.edu.au/au/ journals/MurUEJL/2005/14.html, erişim tarihi: 12.03.2019

27 Söz konusu tanımda geçen "yüksek ve itibarlı sosyal statü” ve "mesleğin icrası" kavramlarının, kavramsal netlikten uzak olduğu ileri sürülerek yapılan eleştiriler için bkz. Wong, prg.42.

28 STRADER, J.Kelly, Understanding White Collar Crime, Matthew Bender \& Company Inc., 2002, s.1.

29 Brettel/Schneider, s.34, kn.12.

30 DEMİRBAŞ, Timur, Kriminoloji, 7. Baskı, Seçkin, Ankara, 2020, s.295.

31 BENSON, Michael L./SIMPSON, Sally S., White Collar Crime: An Opportunity Perspective, Taylor \& Francis Books, 2009, s.21.

32 Benson/Simpson, s.29. 
olarak, günümüzde, alt ve orta tabakaya mensup olup çok iyi bir gelire sahip olmayan, memur ya da serbest meslek sahibi ya da küçük işletmeleri idare eden sıfatını haiz kişilerin de ekonomik nitelik taşıyan suçları işleyebileceğini ifade etmiştir. Yazara göre ayrıca, dürüst bir insan tarafından mesleki bir faaliyet sırasında işlenen her suçu da ekonomik suç olarak kabul etmek mümkün değildir ${ }^{33}$. Modern ceza hukukunun faili değil, fiili esas alıyor olması da fail odaklı bu yaklaşıma yöneltilebilecek bir diğer eleștiridir ${ }^{34}$.

Bu kapsamda 1970 yılında Amerika'da Edelhertz tarafından ortaya atılan bir görüşe göre beyaz yaka suçlarını karakterize eden, failin özelliklerinden ziyade, bu tür suçların fiziksel bir davranış olmaksızın işlenmesi ve suçun işlenmesiyle ağırlıklı olarak bir takım mali avantajların elde edilmesidir. Edelhertz’e göre, beyaz yaka suçlarında ekseriyetle şu unsurlar bulunur ${ }^{35}$ :

i. Suç niyeti gizlidir,

ii. Fail, mağdur/mağdurların dikkatsizliğinden istifade eder,

iii. Mağdurun, aleyhine gerçekleştirilen işlemde rızası olsa da bu rıza, sıhhatli değildir,

iv. Fail, mağdura yönelik eylemin olumsuz sonuçlarını gizleme amacıyla hareket eder,

v. Fail, gizleme amacına uygun olarak sahte bir görünüş (kılıf) oluşturur.

Beyaz yaka suçunu, işlenen fiile göre ele alan bu yeni yaklaşıma ${ }^{36}$ göre beyaz yaka suçu, "klasik suç tiplerinde müşahede edildiğinden farkh olarak fiziksel olmayan yollarla/davranışlarla ve gizleme veya hile yoluyla, belli bir para veya malvarlğııı ele geçirebilmek yahut bir ödemenin gerçekleşmesini veya para yahut malvarlığı kaybını önlemek için yahut da mesleki veya şahsi bir avantaj elde edebilmek adına gerçekleştirilen yasa dışı davranışlar ya da davranış serileri" şeklinde tanımlanabilir ${ }^{37}$. Bu anlamda, sokak suçlarından farklı olarak beyaz yaka suçları, hile, aldatma yahut yasal olmayan bir durumu yasalmış gibi göstererek bunun sağladığı yasadışı avantajlardan faydalanmak için yalan beyanda bulunmak; bunların bazıları da yasadışı amaçlar için kurumsal pozisyonun ya da kamu görevinin sağladığı gücü kötüye kullanmak suretiyle işlenmektedir ${ }^{38}$.

Beyaz yaka suçlarını işleyen faillerin, gerek sahip oldukları yüksek ve itibarlı sosyal statü, gerekse bunların suç işlerken hile kullanarak görünüşte yasal bir durum oluşturmaları dolayısıyla yakalanmaları ve işledikleri suçlar dolayısıyla yargılanarak cezai sorumluluğa tabi tutulmaları

33 Özbek, s.27.

34 Özbek, s.28.

35 Brettel/Schneider, s.37, kn.18.

36 Buna göre, bir suçun beyaz yakalı suç olarak kabulü, failin kim olduğuna göre değil, işlenen davranışın kriminolojik kriterlere nazarında ekonomi hukuku çerçevesinde ele alınıp alınamayacağına göre belirlenir (Meier, s.314, kn.6)

37 SHOVER, Neal, Generative Worlds of White-Collar Crime in: International Handbook of White-Collar and Corporate Crime, (Editors: Henry N. PONTELL, Gilbert GEIS), Springer 2007, s. 81, 82. Bu tanım, her suçun asgari de olsa mutlaka fiziksel bir davranışın gerçekleștirilmesi suretiyle işlendiği, dolayısıyla "fiziksel olmayan" kavramının neyi ifade ettiğinin net olmadığı; keza daha da problematik olarak hile kavramının neye karşılık geldiğinin belirsiz olduğu ve bu tanımın neden sadece bir malvarlığı ya da para yahut da mesleki avantaj elde etme gayesiyle işlenen suçlarla sınırlandığının bir izahının bulunmadığı gibi gerekçelerle eleştirilmiştir. Eleştiriler için bkz. GREEN, Stuart P., The Concept of White Collar Crime in Law and Legal Theory, Buffalo Law Rewiev, Vol. 8:1, s.12,13.

Shover/Hochstetler, s.4,5; 
zordur $^{39}$. Buna paralel olarak Yale Üniversitesi tarafından yapılan araştırmalara göre, sokak suçlarında tutukluluk oranı \%90’a ulaşırken, beyaz yakalı suçlarda bu oran \%56’yı aşmamaktadır ${ }^{40}$.

Bu açıklamalar ışığında, TCK m.164'te düzenlenen suç tipi de hem fiil hem de fail nazara alınarak ortaya konulan tanıma göre beyaz yaka suçu olarak kabul edilebilir. Nitekim Benson/Simpson, beyaz yaka suçunun tanımlanmasında kullanılan, yüksek ve itibarlı sosyal statüye sahip kişilerin, genellikle işletme sahibi ve/veya yöneticisi olan kimseler olduğunu ifade etmişlerdir ${ }^{41}$. Beyaz yaka suçları, ekonomik suçların bir çeşidi olarak kabul gördüğünden ${ }^{42}$, daha önce ifade edildiği üzere, söz konusu suç tipini ekonomik suçlar kapsamında değerlendirmek mümkündür.

\section{Korunan Hukuki Değer Nazarında Suçun Tasnifine Iilişkin Değerlendirme}

Şirket veya kooperatifler hakkında yanlış bilgi verme suçuna, TCK'da, malvarlığına karşı suçların düzenlendiği ikinci kısım, onuncu bölümde yer verilmiştir. Bu bakımdan aynı esası benimseyen mehaz İsviçre hukukunda sistematik bir yorum tarzıyla, suçun ihdasıyla, "şirket veya kooperatife verilen yanlış bilgi neticesinde, şirket veya kooperatiflerle bağlantılı kişilerin aldatılarak malvarlıklarında bir azalma meydana gelmesinin önüne geçilmesinin amaçlandiğı” ifade edilmiştir ${ }^{43}$. TCK m.164'ün gerekçesinde ise suç tanımıyla, "şirket veya kooperatiflerin yönetilmesinde güven ve iyi niyetin korunmasının amaçlandiğı” belirtilmiştir ${ }^{44}$. Buradan hareketle suçun, mevcut düzenleme dikkate alınarak çok hukuki konulu olduğu söylenebilir ${ }^{45}$.

39 Wong, prg.21; DEMİRBAŞ, Timur, Kriminoloji, 7. Baskı, Seçkin, Ankara, 2020, s.295.

40 Benson/Simpson, s.40.

41 Benson/Simpson, s.19.

42 Sulhi Dönmezer, Kriminoloji, Gözden Geçirilmiş 8. Bası, İstanbul, Beta, 1994, s. 57; Güner, s.1421, 1422. Bunun aksine, ekonomik suçun beyaz yaka suçluluğunun bir türevi olduğu, ekonomik suç kavramının, beyaz yaka suçluluğundan daha dar bir çerçevede ele alınması gerektiğine ilişkin bkz. Küçüktaşdemir, s.60, 63.

43 SCHLEGEL, Stephan, Art. 152 StGB, in: Wolfgang Wohlers, Gunhild Godenzi, Stephan Schlegel, Schweizerisches Strafgesetzbuch Handkommentar, 4. Auflage, Stämpfli Verlag AG, 2020, kn. 1; TRECHSEL, Stefan/CRAMERI, Dean, Art. 152 StGB, in: Schweizerisches Strafgesetzbuch Praxiskommentar, 3. Auflage, Die Verlag, 2018, kn.1 (s.892); SCHALLER, Jean Marc, Finanzanalysten-Recht Die Berufstätigkeit der Finanzanalysten im Rahmen des Privat-, Straf - und Aufsichtsrechts, Schultess, 2004, kn.73 (s.139).

44 Benzer görüş için bkz. HANSLIN, Marc, Markt - und Kursmanipulation Art. 143 und Art. 155 FinfraG sowie Art. 122 ff. FinfraV, Dike Verlag, 2017, kn.179 (s.105). Yargitay da madde gerekçesine uygun olarak, bu suçla korunan hukuki yararın, şirket veya kooperatiflerin yönetilmesinde güven ve iyi niyet olduğuna işaret etmiştir (Yarg. 15. CD., 15.12.2016, 2014/9247 E., 2016/9590 K.).

45 ARTUÇ, Mustafa, Malvarlığına Karşı Suçlar, 4. Baskı, Adalet, Ankara 2020, s. 878; BAYRAKTAR, Köksal/YILDIZ, Ali Kemal/AKSOY RETORNAZ, Eylem/AKYÜREK, Güçlï/EVİK, Ali Hakan/KANGAL, Zeynel T./MEMİ̧ KARTAL, Pınar/SINAR, Hasan/SONAY EVIK, Vesile/ALTUNÇ, Sinan/AYTEKİN İNCEOĞLU, Asuman/BOZBAYINDIR, Ali Emrah/ERMAN, Barıș, Özel Ceza Hukuku (Malvarlığına Karşı Suçlar), Cilt IV, Onikilevha, İstanbul, 2018, s.411. Bu suçla hem şirket veya kooperatiflerle bağlantılı kişilerin aldatılarak malvarlıklarında bir azalma meydana gelmesinin önüne geçilmesi, hem de şirket veya kooperatiflerin yönetilmesinde güven ve iyi niyetin korunmasının amaçlandığ 1 hususunda bkz. JECKER, Marc Jan, Die konkurs - und strafrechtliche Aufarbeitung der Kriminalinsolvenz, Dike Verlag, 2009, s.216; LANZ, Martin/RYSER, Roland M., Strafrechtliche Aspekte der Ad-hoc-Publizität Inwiefern sind Verstösse gegen Art. 72 KR-SWX nach Art. 152 StGB strafbar?, SZW 2008, s.30; WEBER, Rolf H./BAUMANN, Simone, Neukonzeption der Rechtsprechungsordnung im Börsenwesen, Schweizer Schriften zum Finanzmarktrecht Band/Nr. 103, 2012, s.82. Bir suç ile korunan birden fazla menfaatin bulunması mümkündür. Ekonomik suçlarda önemli olan, korunan bu hukuki yararlardan, ekonomik düzenin korunmasının ön planda olmasıdır. (Aytekin-İnceoğlu, s.9). 
TCK’da söz konusu suç tipine yer verilerek, şirketler ve kooperatifler hakkında Türk Ticaret Kanunu’nda ve Kooperatifler Kanunu’nda yer verilen hükümlerin uygulanmasını sağlamak adına $^{46}$, ekonomik düzenin yapı taşları olan şirketler ve kooperatiflerin faaliyetlerine duyulan güvenin korunmasının amaçlandığı aşikardır ${ }^{47}$. Bu noktada, ekonomik suçu kriminolojik açıdan, suç dolayısıyla ortaya çıkan sosyal zararı dikkate alarak açıklayan görüşün kabul ettiği, "mevcut ekonomik sisteme bir bütün olarak veya münferit kurumların faaliyetleri özelinde duyulan güveni ihlal eden ve dolayısıyla söz konusu ekonomik sistemin varlı̆̆nı veya işleyişini tehlikeye atan suç" șeklindeki $\operatorname{tanım}^{48}$, normatif alanda karşılık bulmuştur ${ }^{49}$.

Kanun koyucunun, ekonomik düzenin sağlanmasına verdiği değer o denli baskındır ki dolandırıcılık suçu ve dolandırıcılığın özel bir şeklini oluşturan bilgiye dayalı piyasa dolandırıcılı̆̆ı (SPKn m.107/2) suçunu oluşturan davranışlar dışında, adeta bu alanda bir cezalandırma boşluğu doğmaması adına, herhangi bir zarar yahut fail lehine ortaya çıkan bir menfaat aranmaksızın, şirketler veya kooperatiflerle ilgili yanlış bilgi verilmesi suç olarak kabul edilmiştir. Nitekim aşağıda ayrıntılı olarak izah edileceği üzere maddede, gerçeğe aykırı bilginin, ilgililerin zarara uğratacak nitelikte olması gerektiği belirtilerek bu tarz bilginin önemli olması lüzumuna işaret edilmiştir. İlgililerin zarara uğraması, suçun oluşması bakımından bir netice olarak aranmamıştır.

Malvarlığına karşı işlenen suçlar, kişilerin mülkiyet hakkını korumakta olup ancak ekonomik çıkar amacıyla işlenen suçlar başlı̆̆ı altında ve geniş anlamda - dolaylı olarak - ekonomik suç kapsamında değerlendirilebilirler. Buna karşılık, yukarıda ayrıntılı açıklamaya çalıştığımız üzere, ekonomik ceza hukukunun çekirdek alanında yer alan suçlarla, ekonominin güven içerisinde işleyişi muhafaza edilmek istenmektedir. Dolayısıyla, malvarlığına karşı suçların salt iktisadi bir faaliyetin sonucu olarak ortaya çıkmadıkları söylenebiliir ${ }^{50}$. Bu çerçevede, bir yandan şirket ve kooperatiflerin ekonominin işleyişindeki önemi, öte yandan madde gerekçesinde, suç tanımıyla yalnızca şirket veya kooperatiflerin idaresinde güven ve iyi niyetin korunmasının amaçlandığına işaret edilmesi, bu suçun TCK'da malvarlığına karşı işlenen suçlar başlğ̆ı altında ihdas edilmesini eleştiriye açık hale getirmektedir. Gerçekten suçun ihdasıyla, bireylere ait malvarlığı menfaatlerine yönelik sağlanan korumanın hedef değil, yansıma olduğunu söylemek gerekir. Dolayısıyla bu suça, şirketler ve kooperatiflere ilişkin bütüncül yaklaşımı korumak adına TCK’da, Üçüncü Kısım Dokuzuncu Bölüm itibarıyla düzenlenen "Ekonomi, Sanayi ve Ticarete Karşı İşlenen Suçlar" içerisinde yer verilmesi veyahut da suçun, Türk Ticaret Kanunu ve Kooperatifler Kanunu’nda ayrı hükümlerle ihdas edilmesi daha isabetli olurdu.

46 Hanslin, kn.179.

47 Suç tipinin ihdasıyla, ekonomik suçlulukla mücadele edilmesinin amaçlandığı ve ekonomik faaliyetlerin hızla gelişmesi ve çeşitlenmesi karşısında kanun koyucunun bu amaca uygun olarak İsviçre Ceza Kanunu m.152'nin uygulama alanını genişlettiği hususunda bkz. SCHMID, Niklaus, Titel Das neue Vermögens - und Urkundenstrafrecht, SJZ 91/1995, s.7.

48 Tanım için bkz. Meier, s.315, kn.8

49 Ekonomik suçlarda korunan hukuksal yararın bireysel değil kamusal olduğu, ekonomik suçların maddi unsurları itibarıyla da ekonomik düzene zarar veren, işleyiş bakımından tehlike arz eden, toplumsal güveni zedeleyen eylemlerden ibaret olduğu hususunda bkz. Dursun (Gizem), s.858. 


\section{Suçun Unsurları}

\section{A. Maddi Unsurlar}

\section{Fiil}

TCK m.164'te yaptırıma bağlanan fiil, bir bütün halinde, "kamuya yapılan beyanlarda veya genel kurula sunulan raporlarda veya önerilerde ilgililerin zarara uğramasına neden olabilecek nitelikte gerçeğe aykırı önemli bilgiler vermek veya verdirtmek” şeklinde tanımlanmıştır. Fiili, ortak mahiyette niteleyen özellikler hariç tutularak ifade etmek gerekirse, burada tipik davranış, bilgi verme veya bilgi verdirtme olarak tespit edilebilir.

Bilgi verme, fail tarafından bizzat gerçekleştirilebilir. Buna karşılık bilgi verdirtme, bir başkası aracılığıyla bilginin verilmesi anlamına gelir. İştirak hükümleri açısından özellik taşıması bakımından, bu davranışlardan bilgi verdirtme ile ilgili açıklamalara, fail başlı̆̆ı altında ayrıntılı olarak yer verilecektir.

\section{a. Suç Teorisinde, Fiile Ilişskin Kabul Edilen Tasnifler Yönünden}

TCK m.164’te tanımlanan davranış, esas itibarıyla icrai özellik gösterir. Nitekim kamuya beyanda bulunulması, genel kurula gerçeğe aykırı bilgi verilmesi veya verdirtilmesi, failin, somut olarak gözlemlenebilen aktif bir davranışta bulunmasını gerektirir ${ }^{51}$.

Bununla birlikte, anılan davranışın ihmal suretiyle icraen gerçekleştirilmesi de mümkündür ${ }^{52}$. Bu kapsamda ihmalin, TCK m.164’te tanımlanan icrai davranışa denk olması, bunun için failin neticeyi önleme yükümlülüğünün bulunması ve buna aykırı olarak ihmal göstermesi gerekir ${ }^{53}$. Örneğin, TTK m.369 uyarınca özen borcu altında olan bir yönetim kurulu üyesi, yönetim kurulunun genel kurula sunduğu raporda gerçeğe aykırı önemli bilgiler yer aldığını bilmesine rağmen ihmalde bulunmama yükümlülügü çerçevesinde söz konusu raporun genel kurula açıklanmasına engel olmadığında, sadece raporu açıllayan yönetim kurulu üyesi değil, raporun açıklanmasına engel olmayan yönetim kurulu üyesi bakımından da suç oluşacaktır ${ }^{54}$.

İsviçre hukukunda, sermaye piyasası araçlarını ihraç eden, ihraç etmek üzere Kurula başvuruda bulunan veya sermaye piyasası araçları halka arz edilen tüzel kişileri ve SPKn’ye tabi yatırım fonlarının yöneticileri tarafından (ihraççı) ${ }^{55}$, bilgi verme yükümüne aykırı olarak hiçbir bilgi paylaşılmamasının, bu suç kapsamında ve İsviçre Ceza Kanunu m.152'de yer verilen "eksik bilgi verme" fiili çerçevesinde değerlendirilip değerlendirilemeyeceği tartışılmıştır. Hukukumuz yönünden belirtmek gerekir ki TCK m.164’te eksik bilgi vermenin suç oluşturduğuna dair bir açıklık yoktur. Kanun koyucunun,

51 Lanz/Ryser, s.32.

52 Bu yönüyle suçun görünüşte ihmali suç olduğu hususunda bkz. Lanz/Ryser, s.34.

53 Jecker, s.216, 217.

54 BAYRAKTAR ve diğer yazarlar, s.416, 417.

55 İhraççının tanımı için bkz. SPK m.3/1-h. 
madde metninde tanımladığı icrai davranışın, garantörsel yükümlülük altındaki kişi tarafından ihmal suretiyle gerçekleştirilmesi ile ihmal göstererek hiç bilgi verilmemesi birbirinden farklı olup bilgi vermek yönünden ihmalde bulunmanın icrai bir davranışla irtibatı kurulmaksızın suç olarak kabulü mümkün değildir ${ }^{56}$.

Fail tarafından yapılan açıklamanın, sunulan raporların veya önerilerde yer alan bilgi/bilgilerin gerçeğe aykırı olduğu bilinerek doğruymuş gibi gösterilmesi ve söz konusu bilgi/bilgilerin önemli olması, suçun oluşması bakımından yeterlidir. Kanun koyucu, bu suçta bir netice olarak ilgililerin malvarlıklarında zarar meydana gelmesini ${ }^{57}$, failin bir fayda sağlamasını ${ }^{58}$ yahut tipik davranışın somut olarak bir zarar tehlikesi meydana getirmesini aramamıştır. Failin soyut tanımda öngörülen davranışı gerçekleştirmesiyle suç tamamlanır. Bu bakımdan söz konusu suç, ekonomik suçların tamamında karşılaşıldığı gibi, herhangi bir sosyo-kültürel veya ahlaki değere aykırılık taşımayan, sadece kamu düzeninin işleyişi yönünden gerekli görülerek normatif düzenlemelerle yasaklanan mala prohibita ${ }^{59}$ olarak da kategorize edilen suçlardandir ${ }^{60}$. Netice itibarıly bu suçun, sırf hareket ve soyut tehlike suçu niteliğinde olduğu ifade edilebilir ${ }^{61}$.

Belirtmek gerekir ki suçun şirket veya kooperatife dair gerçeğe aykırı bilgi vermek suretiyle işlenmesi nedeniyle, somut olayda ilgili kişinin zarara uğramış olması kuvvetle muhtemeldir. Örneğin sermaye veya şirketin ticari faaliyetleriyle ilgili genel kurula verilen gerçeğe aykırı bilgi nedeniyle ortaklar, şirket hisselerini satmış olabilirler. Şirketin ticari durumunun iyi olduğuna dair gerçek dışı bilgi nedeniyle, başka bir yatırım yapma kararından vazgeçilmesi halinde de kısa vadede uğranılan bir zarar söz konusudur.

Maddede öngörülen "vermek veya verdirtmek" şeklindeki davranışlardan herhangi birinin işlenmesi yeterlidir. Bu yönüyle suç, seçimlik ve bağh hareketlidir ${ }^{62}$.

56 SCHLEIFFER, Patrick/REINWALD, Urs, Management-Transaktionen: Rechtsgrundlagen, Umsetzung und Sanktionen, GesKR 2012, s.405.

57 Lanz/Ryser, s.33.

58 BRENNER, Beat, Strafanzeige gegen Organe der SAirGroup Artikel 152 und 158 StGB im Visier, Recht im Spiegel der NZZ, Nr.2, 2001, s.60.

59 Kavram ve ahlaki bir değere dayanan suçlar için kullanılan "Mala in Se" kategorisindeki suçlardan ayrımı için bkz. Yazar belirtilmemiştir - The Distinction between 'Mala Prohibita' and 'Mala in Se' in Criminal Law, Columbia Law Review, Vol.30, No.1, 1930, 74-86. (JSTOR, www.jstor.org/stable/1114831, erişim: 7.11.2020)

60 Mala in Se ve Mala Prohibita ayrımının eleştirisi için ayrıca bkz. GRAY, Richard L., Eliminating the (Absurd) Distinction Between Malum In Se and Malum Prohibitum Crimes, Washington University Law Review, Volume 73, Issue 3, 1995 (Northwestern University/Washington University Law and Linguistics Conference), s.13691398.

61 DONATSCH, Andreas, Art. 152 Unwahre Angaben über kaufmännische Gewerbe, in StGB/JStG Kommentar, 20. Überarbeitete Auflage, Orell Füssli Verlag, 2018, s.375, kn.1; Lanz/Ryser, s.30. Ekonomik suçların genel özellikleri itibarıly tehlike suçu mahiyetinde olduğu yönünde bkz. Aytekin-İnceoğlu, s.11; Mahmutoğlu, s.41; Küçüktaşdemir, s.125.

62 Bayraktar ve diğer yazarlar, s.417. 


\section{b. Bilginin Özellikleri}

\section{aa. Gerçeğe Aykırılık}

TCK m.164 uyarınca, suçun oluşması için failin kamuya yaptığ sunduğu rapor ve önerilerde yer alan bilgiler, bazı özelliklere sahip olmalıdır. Madde metninde ve gerekçesinde bunlardan ilki, bilginin gerçeğe aykırı olması şeklinde belirtilmiştir.

Gerçeğe aykırılık, bu ifadede geçen gerçeklik kelimesine karşıtlık üzerinden tarif edilmektedir. Buna göre gerçeğe aykırılık, gerçek dışılık demektir ${ }^{63}$. En genel anlamıyla gerçeklik, dış dünyada nesnel bir varoluşa sahip varlıkların, insan zihninden bağımsız olarak var olan şeylerin bütünüdür ${ }^{64}$. Bu manada, gerçeğe aykırılık ile kastedilen, gerçekliğin kişinin algısına göre değişebilen sübjektif anlamı değil, bilginin objektif esaslara göre gerçeğe aykırı olmasıdır ${ }^{65}$. Fail tarafından ortaya konulan bilgi, ilişkin olduğu konuyla uyumlu ise, bu bilgi gerçektir; aksi halde gerçeğe aykırıdır ${ }^{66}$. Dolayısıyla söz konusu suç yönünden bilginin, objektif esaslara göre kısmen yahut tamamen gerçekle çatışma halinde olması gerekir $^{67}$. Şirket veya kooperatifin mevcut durumuyla bağdaşmayan her bilgi, gerçeğe aykırı bir bilgi olacaktır. Bilginin şirketin lehine yahut aleyhine olmasının, suçun oluşumuna etkisi yoktur.

Maddenin kenar başlığı, "şirket veya kooperatifler hakkında yanlış bilgi” olarak belirlenmiştir. Dolayısıyla burada, yanlış bilgi ile gerçeğe aykırı bilgi arasında bir fark olup olmadığına da açıklık getirmek gerekir. Bir nesne hakkında yargıda bulunan, insanın aklıyla ulaşabileceği bir olguya ilişkin olan ifadeler, bir bilgiyi barındırır. Bu ifadelerin, hakkında yargıda bulunduğu nesneye objektif açıdan uygun olmaları halinde doğru, aksi durumda yanlış oldukları sonucuna ulaşılır. Görüldüğü gibi, gerçeğe aykırı bilgi ile yanlış bilgi arasında sıkı bir irtibat vardır. Bu itibarla, madde kenar başlığı ile metinde kullanılan ifadeler arasında dikkate değer bir farklılık olduğu söylenemezse de yorum farklılıklarına neden olmamak adına ve başlık ile içeriğin uyumlu olması gerektiğinden hareketle, kanun koyucunun düzenleme tarzının eleştiriye açık olduğu kabul edilmelidir.

Verilen bilgide eksiklikler bulunması nedeniyle bilgi gerçeğe aykırılık arz ediyorsa, suçun oluşacağı kabul edilmelidir 68 .

\section{bb. Bilginin Önemli Olması}

TCK m.164'te, bilgi bakımından aranan ikinci özellik, bilginin önemli olması şeklinde ifade edilmiştir. Bu kapsamda bilginin içeriğinin, ilgililerin malvarlığı değerini zarara uğratan yahut zarara

63 Bkz. http://sozluk.gov.tr

64 CEVİZCI, Ahmet, Felsefe Sözlüğü, 7. Baskı, Paradigma Yayıncılık, İstanbul, 2010, s.710.

65 Schlegel, kn.3.

66 Bayraktar ve diğer yazarlar, s.413. Gerçeğin ontolojik açıdan anlamı hususunda bkz. CANPOLAT, Can, Ceza Muhakemesi Hukukunun Amacı: “Objektif gerçeğin keşfi mi? Yargısal (kazai) bir gerçeklik inşa etmek mi?”, Erciyes Üniversitesi Hukuk Fakültesi Dergisi, C.15, S.2, s.462.

67 Gerçeğe aykırılığın objektif esaslara göre belirlenmesi gerektiğine ilişkin ayrıca bkz. Dursun, Gerçeğe Aykırılıktan Doğan Suçlar, s.153 vd.

68 Lanz/Ryser, s.31. 
uğratma tehlikesi yaratan bir mahiyette olması; suçun haksızlık içeriğini karşılayan bir öneme sahip bulunması gerekir. Maddede, bilginin sıfatı olarak yer verilen “önemli” ifadesi ile anlatılmak istenen de budur. Bu yönüyle şirket veya kooperatifler hakkında yanlış bilgi verme, sırf gerçeğe aykırılık nazara alınarak ihdas edilen bir suç değildir. Suçun oluşması bakımından nitelikli bir gerçeğe aykırılık aranır ${ }^{69}$.

Sermayeye, yönetime ve ticari faaliyete ilişkin olup gerçeğe aykırı olan her bilginin bu önemi haiz olduğu söylenebilir. Bunun dışında kalan konulardaki bilgilerin önemi, her somut olaya göre belirlenmelidir. Örneğin İsviçre Yüksek Mahkemesi, konuyla ilgili bir kararında ${ }^{70}$, bir şirketin antetli kağıdında kullanılan isim ile ticaret siciline kayıtlı olan isim arasında farklılık bulunması durumunda, bu suçun oluşmayacağını kabul etmiştir. Keza şirketin aktif veya pasiflerine ait bilgiler bilançoda uygun şekilde gösterilmemekle birlikte, bu durum, şirketin genel mali durumu bakımından önemli bir değişikliğe sebep olmuyorsa, bilgi önemli değildir ${ }^{71}$.

Ürün kusurlarının, şirketin akdettiği sözleşmeden kaynaklanan birtakım yükümlülüklerin, şirket veya kooperatif hakkında ikame edilmiş davaların akıbetinin ${ }^{72}$, şirketin çevreye verdiği zarar dolayısıyla alınması gereken önlemlere ilişkin mali veriler hakkında gerçeğe aykırı raporlamaların ${ }^{73}$, yatırımcıyı hisse almaya, satmaya, alım emrini geri çekmeye, kredi kullanım iradesinden vazgeçmeye yönelten gerçeğe aykırı bilgilerin ${ }^{74}$, kooperatifin arsasının kamulaştırma yahut kentsel dönüşüm kapsamına alındığına ilişkin bilginin ${ }^{75}$ önemli olduğu kabul edilir. Keza banka personelinin ücretlendirme politikalarına ilişkin raporların, anonim şirket olarak kurulan bankanın kısa vadeli karlılığı ile ilişkilendirilerek bankanın taşıyabileceği risk düzeyini aşan risk alımını teşvik edici mahiyette ve uzun vadeli finansal güç ve sermaye yeterliliğine uygun düşmeyen gerçek dışı bilgiler barındırması da önemli gerçeğe aykırı bilgiye örnek gösterilebilir ${ }^{76}$. Şirketin gelecekteki mali durumu ile ilgili olumlu yahut olumsuz görüşler beyan edilmesi, henüz gerçekliği teyit edilemediğinden, suç oluşturmaz. Buna karşılık, herhangi bir somut ekonomik veriye dayanmayan ve şirketin gerçek durumuyla bağdaşmayan kazanç uyarılarının, somut olayın özelliklerine göre titizlikle değerlendirilmesi gerekir 77 .

69 "Sırf gerçeğe aykırılıktan doğan suçlar-nitelikli gerçeğe aykırılığın suç kabul edildiği haller" şeklindeki ayrım ve TCK m.164'te düzenlenen suçun, nitelikli gerçeğe aykırllık kapsamında değerlendirilmesine ilişkin bkz. Dursun, Gerçeğe Aykırılıktan Doğan Suçlar, s.178 vd.

70 BGE 104 IV 77, 14.4.1978, S.85. (www.bger.ch, erişim tarihi: 08.09.2020). Söz konusu kararda belirtilen düşünceyle aynı yönde bkz. LEHMANN, Peter, Die "kleine Aktienrechtsrevision" (Teil 2) - Neuerungen in den Bereichen Aktionärsrechte, Firma, Handelsregister, GesKR 2007, s.426.

71 Donatsch, Buchführung, s.206.

72 “...yönetim kurulu tarafından arsa sahiplerinin açmış olduğu dava ve aşamalarından genel kurula yeterli derecede bilgi verildiği ve ödeme yapılması konusunda genel kurulu kararı alındığı..." (Yargıtay 15. CD., 20.2.2018, 2016/545 E., 2018/1165 K.)

73 KISSLING, Mischa, Der Mehrfachverwaltungsrat (Die Tätigkeit in Verwaltungsräten mehrerer Aktiengesellschaften aus Sicht des Zivil-, Straf-, Wettbewerbs-, Steuer - und Sozialversicherungsrechts, Schultess, 2007, kn.616.

74 Hanslin, kn.179.

75 Yargitay 15. CD., 20.2.2017, 2017/14882 E., 2017/6279 K.

76 Benzer görüş için JUTZI, Thomas, Unternehmenspublizität Grundlinien einer rechtlichen Dogmatik zur Offenlegung von unternehmensbezogenen Informationen, Stämpfli Verlag, 2017, kn.528.

77 Lanz/Ryser, s.31. 
Daha önce belirtildiği üzere, bu suçun oluşması için herhangi bir zararın ortaya çıması aranmamış olsa da kooperatif veya şirketle ilgili kişiler işlenen fiil dolayısıyla zarara uğramış olabilir. Diğer bir deyişle, işlenen fiil dolayısıyla bu kişilerin malvarlıklarında bir azalma meydana gelmiş olabilir. $\mathrm{Bu}$ durumda, zararın miktarı, bilginin önemli olup olmadığı değerlendirmesinde dikkate alınmaz. Bu bakımdan örneğin, bir yatırımcının, şirketle ilgili gerçeğe aykıı bilgi nedeniyle sahip olduğu hisseler üzerindeki tasarrufu düşük miktarda olsa da bu bilginin, yatırımcı davranışını etkilemesi nedeniyle önemli olduğu sonucuna varılmalıdır ${ }^{78}$.

\section{cc. Bilginin, Şirket veya Kooperatife Illişkin Bulunması}

TCK m.164’te, failin verdiği yahut verdirttiği gerçeğe aykırı bilginin şirket hakkında olması gerektiğine ilişkin bir ibareye yer verilmemekle birlikte, maddenin kenar başlığı, "şirket veya kooperatifler hakkında yanlış bilgi” şeklinde belirlendiğinden, bu gerekliliğin mevcudiyeti hususunda bir tereddüt yoktur. Bununla birlikte, gerçeğe aykırı bilginin ilişkin olduğu şirketin türü ile ilgili ne madde metninde ne de gerekçede bir tespit mevcuttur. Failin özellikleri zikredilirken, yönetim, denetim kurulu üyelerinden, tasfiye memurundan söz edilmiş olması, gerçeğe aykırı bilginin genel kurula sunulması gerektiğine işaret edilmesi dolayısıyla, ticari şirketlerin bu kapsamda değerlendirilmesi gerektiğinde kuşku yoktur. Aynı şekilde, gerçeğe aykırı beyanların kamuya yönelik olması da şirket faaliyetleri ile ilgili bilgilerin kamu nezdinde önem taşıması halinde söz konusu olabileceğinden, SPKn'nin 16'ncı ve 3'üncü maddeleri uyarınca hisseleri halka arz olunan ortaklıkların da maddede zikredilen şirket kavramına dahil olduğu açıktır.

$\mathrm{Bu}$ hususta tereddütlü olan, teknik manada genel kurul, yönetim kurulu, denetim kurulu gibi yapıları bulunmayan, ancak tasfiyesinde ortakların oybirliği ile bir tasfiye memuru atayabileceği, ortak ve yöneticisi bulunan adi ortaklıkların da maddenin uygulama alanında olup olmadığıdır. Konuyla ilgili olarak madde gerekçesinde, şirket veya kooperatifler alanında kamunun veya sözü geçen kuruluşların genel kurullarının aldatılmalarının önüne geçilmesinin amaçlandığı belirtilmiş, maddenin kenar başlğ̆ında da "şirket" kavramına yer verilmiştir. Adi ortaklı̆̆ın, 6098 sayılı Borçlar Kanunu’nun 609 ve devamı maddelerinde düzenlendiği, ticari işletme mahiyetinde olmadığı dikkate alındığında, kanun koyucunun, adi ortaklıkları hükmün tatbikat alanı dışında bıraktığı söylenebilir. İsviçre Ceza Kanunu m.152'de, ticaret şirketleri yanında, ticari faaliyette bulunan herhangi bir işletmeden bahsedilerek, hükmün uygulamasına adi şirketler de dahil edilmiştir ${ }^{79}$.

Trechsel/Crameri, kn.7 (s.894).

Schmid, s.7; Trechsel/Crameri, kn.3 (s.892). 


\section{c. Gerçeğe Aykırı Bilginin Veriliş Biçimine Ilişkin Özellikler}

\section{aa. Beyanın Kamuya Yöneltilmesi}

TCK m.164'te, kamuya yapılan beyanlara özellikle yer verilmesi, ticari hayatta geniş bir kitleye hitaben paylaşılan gerçeğe aykırı bilgilerin, ilgililerin, yatırım aracı olarak kullandıkları varlıklar hakkındaki tasarruflarını etkileme riskini artırmas ${ }^{80}$ ve şirketlerin idaresine duyulan güveni daha derin etkileme imkanına sahip olması ile bağlantılıdır. Madde gerekçesine göre, beyanın kamuya yöneltilmesinden maksat, basın ve yayın yoluyla veya postayla prospektüsler gönderilerek belirli olmayan kişilere hitap edilmesi ve bunlara yanlış bilgi verilmesidir ${ }^{81}$. Söz gelimi, ticaret sicilinde yayımlanması gereken konularla ilgili olarak gerçeğe aykırı bilgiler paylaşılması, yayın yoluyla kamuya beyanda bulunulması kapsamında değerlendirilmelidir. Yargıtay da konuyla ilgili olarak verdiği bir kararında ${ }^{82}$; “... Çukurdere Madencilik Sanayi ve Ticaret Ltd. Şti’nin Anonim şirkete dönüştürülmesi işlemlerinin yapılması sırasında katılanın bilgi ve onayı dışında denetçi olarak sözleşmeye isminin yazıldı̆̆ı, yönetim kurulu kararı alındı̆̆ı ve bu kararın 03/08/2009 tarihinde Ticaret Sicil Gazetesinde tescil ve ilan edildiği, Çukurdere Anonim Şirketinin 09/10/2009 tarihli bir kararıla yönetim kurulunun tekrar toplanarak denetçi olarak belirlenen katılanın yerine başkasını seçtikleri, bu kararı da 13/10/2009 tarihinde tescil ile 16/10/2009 gününü Ticaret Sicil Gazetesinde ilan ettirdikleri, katılanın Anayasa Mahkemesi üyesi olup başka herhangi bir görev alamayacă̆ı, ana sözleşme altında imzası bulunan şirket ortakları olan sanıklar F.. A.. ile İ.. G..ün şirket veya kooperatif hakkında yanlış bilgi verme suçunu işledikleri iddia edilen olayda, her ne kadar sanıklar savunmalarında şirket nevi değişikliği işlemlerinin şirket avukatı tarafından vekaleten yapıldı̆̆ını, kendilerinin olaydan haberlerinin olmadığını beyan etmişler ise de, tanık olarak dinlenen F.. Ö.. ifadesinde şirketin nevi değişikliği sözleşmesini kendisinin hazırladiğını, ancak hazırladığı ana sözleşmeyi de sanıklara gösterdiğini ve onların onayını aldığını beyan etmesi ve dosya içeriğine göre sanıkların suçtan kurtulmaya yönelik savunmalarına itibar edilmemiş, toplanan delillere göre sanıkların katılanın bilgisi ve onayı dışında kendisini şirket denetçisi olarak göstermek suretiyle üzerlerine atılı suçu işledikleri...” diyerek benzer sonuca ulaşmıştır.

Kamuyu aydinlatma ilkesinin ${ }^{83}$ sonucu olarak TTK m.1524'e göre, "denetime tabi olan sermaye şirketleri ${ }^{84}$, kuruluşlarının ticaret siciline tescili tarihinden itibaren $\ddot{u} c ̧$ ay içinde bir internet sitesi

80 Benzer görüş için bkz. EVİK, Ali Hakan, Sermaye Piyasası Kanununda Düzenlenen Güveni Kötüye Kullanma ve Sahtecilik Suçları II, Ceza Hukuku Dergisi, S.42, Nisan 2020, s.42.

81 “...katılan tarafından yapılan icra takibine, samığın kooperatif başkanı olarak, borca itiraz dilekçesi verip, herhangi bir borcu bulunmadığ şeklindeki beyanın, kamunun gerçeğe aykırı bir şekilde yanıltılmasının söz konusu olmadığı...” (Yargıtay 15. CD., 15.12.2016, 2014/9247 E., 2016/9590 K.)

82 Yargitay 15. CD., 20.10.2015, 2013/15563 E., 2015/30330 K.

83 "Pay sahiplerinin menfaatlerine zarar verebilecek risklere karşı öngörülen tedbirlerinden ilki, pay sahiplerinin şirketin faaliyeti, işlemleri, ekonomik ve mali durumu hakkında bilgi sahibi olmasını sağlamaya yönelik haklardır. Bu haklar, anonim şirkette yönetimi elinde bulunduranları, şirket kaynaklarını ve imkanların hukuka ve dürüstlük kuralına uygun bir biçimde kullanmaya zorlayacak yetkiler içerir. Bu amaca hizmet eden temel ilke, kamuyu aydınlatma ilkesidir. Kamuyu aydınlatma, şirket yönetimi tarafindan, işletmelerin mali durumu ve ekonomik faaliyeti konusunda verilen bilgilerin, yapılan açıklamaların tamamın ifade eder." ATALAY, Oğuz, Anonim Şirketlerde Bilgi Alma ve İnceleme Haklarının Mahkeme Aracilığıyla Kullanılması, in: Prof. Dr. Hakan PEKCANITEZ’e Armağan (Dokuz Eylül Üniversitesi Hukuk Fakültesi Dergisi, C. 16, Özel Sayı 2014,) s. 57.

84 Halen yürürlükte olan 26.03.2018 tarih ve 2018/11597 saylı Bağımsız Denetime Tabi Şirketlerin Belirlenmesine Dair 
açmak ve bu sitenin belirli bir bölümünü şirketçe kanunen yapılması gereken ilanların yayımlanmasına özgüleme" yükümlülüğü altındadır ${ }^{85}$. Bu kapsamda denetime tabi sermaye şirketinin internet sitesinde kamu ile paylaşılan bilgilerin gerçeğe aykırılığı, bu suçun oluşmasına neden olacaktır. Şirketlerle ilgili kamusal alanlarda kurulan reklam panolarına verilen ilanlarda bu tarz bilgilerin yer alması durumunda da benzer sonuca varılabilir. Ayrıca söz gelimi, şirket yönetim kurulu başkanının bir gazeteci ile yaptığı röportaj sırasında aktardığı gerçek dışı beyanlar da anonim birden fazla kişiye paylaşılacağı bilindiğinden, kamuya yapılmış sayılır ${ }^{86}$.

Bir bilginin kamuya açıklanmış sayılması, yalnızca belirsiz sayıda kişiye değil, aralarında kişisel ilişki bulunmayan çok sayıda kişiye yönelik beyanları da kapsar ${ }^{87}$. Ancak bunun için gerçeğe aykırı beyanın, doğrudan veya tek bir aracı vasıtasıyla birden fazla kişiye ulaştırılması zorunludur. Söz gelimi, bir kişinin gönderdiği mailin birden fazla kişi tarafından başka üçüncü kişilere iletilmesi, bu yönde ortak bir irade bulunsa da kamuya bildirim kapsamında değerlendirileme ${ }^{88}$.

SPKn'ye tabi şirketler açısından kamuyu aydınlatma ilkesinin şekli yönü, şirketlerle ilgili bilgilerin belli araçlarla kamuya sunulması, maddi yönü ise sunulan bilginin yeterliliğinin, doğruluğunun, açıklığının, karşılaştırılabilirliğinin bulunmasıdır ${ }^{89}$. Bu çerçevede sermaye piyasası araçlarının ihracı sürecinde, SPKn’ye göre hazırlanması gereken ve ihraççıya, varsa garantöre, garantinin niteliğine ve ihraç edilecek sermaye piyasası araçlarına ilişkin bilgiler içeren izahnamede ${ }^{90}$ yer alan yanlış, yanıltıcı ve eksik bilgiler nedeniyle, ihraççının veya halka arz eden şirketin yönetim kurulu üyelerinin TCK m.164 dolayısıyla sorumlulukları söz konusu olabilir. Nitekim İsviçre hukukunda, Borsa Düzenleme Kurulu tarafından ihdas edilerek 2.1.2020 tarihinde yürürlüğe giren, halka arz edilecek hisse senetlerinin kote edilmesine (kaydedilmesi) ilişkin kuralların düzenlendiği regülasyonun (KR - Kotierungsreglement ${ }^{91}$ - $^{92} 56^{\prime}$ nc1 maddesine göre ${ }^{93}$ (f.2), yönetim işlemlerinde yatırımcının bilgilendirilmesi ve piyasa dolandırıcılığının önüne geçilmesi amacına yönelik olarak, çıkarılan hisse senetleri öncelikli olarak SIX Swiss Exchange AG'de (=İsviçre Borsası) kote olan

Bakanlar Kurulu Kararı uyarınca, denetime tabi olan sermaye şirketleri, "Karara Ekli (I) ve (II) Sayılı Liste Kapsamında Yer Almayan ve Halka Açık Sayılmayan Şirketler", "Herhangi Bir Ölçüte Tabi Olmaksızın Denetim Kapsamında Olan Şirketler" ve "Daha Düşük Ölçütler Belirlenen Özel Şirketler" şeklinde üçlü bir ayrıma göre belirlenmiştir. Birinci ve üçüncü kategoride, şirketin aktiflerinin toplam değeri, yıllık satışlardan ortaya çıkan net hasılatı ve çalışan sayısı dikkate alınmıștır.

85 Söz konusu hükmün, çoğunluğun gücüne engel olmak ve bu gücü, diğer menfaat sahiplerini gözetecek şekilde sınırlandırmak amacıyla getirilmiş doğrudan düzenlemeler kapsamında değerlendirilmesine ilişkin bkz. Evik, s. 49.

86 Schlegel, kn.4. Yanlış bilginin, kamuyla paylaşılmak üzere belli bir kişiye iletilmesi de bu kapsamdadır. (Schleiffer/ Reinwald, s.405)

87 Schlegel, kn.4.

88 BGE 104 IV 77, 14.4.1978, S.85. (www.bger.ch, erişim tarihi: 14.09.2020).

89 DUMAN, Haluk, Sermaye Piyasasının Etkinliği Açısından, Kamunun Aydınlatılması Sürecinde, Şirket Çevresinin İhtiyaç Duyduğu Bilginin Özellikleri: İMKB’de Bir Uygulama, Muhasebe ve Finansman Dergisi, Nisan 2011, s.111, 112.

90 Bu izahnameler kamuya açıllanmaktadır.

91 Bkz. www.six-exchange-regulation.com (erişim tarihi: 22.09.2020)

92 Regülasyonun amacı, ihraççılara, borsa işlemlerine mümkün olduğunca özgür ve eşit erişim ile yatırımcılara, ihraççıların kalitesi ve menkul kıymetlerin özellikleri konusunda şeffaflık sağlamak şeklinde belirlenmiştir (m.1).

93 Maddede, yönetim işlemlerinin açıklanmasına (=Offenlegung von Management-Transaktionen) ilişkin hükümlere yer verilmiştir. 
ihraççllar, yönetim kurulu üyelerinin veya şirket yönetiminin, finansal araçlar bakımından katılma hakkı ile ilgili işlemlerini, en geç işlemin yapıldığı günü takip eden iki iş günü içerisinde bildirmekle yükümlüdürler. Maddenin 5'inci fikrasında ise, bu bilgilerin kamuya duyurulması öngörülmektedir. Söz konusu bilgilerin gerçeğe aykırılı̆̆ının, şirket hakkında yanlış bilgi suçunu oluşturduğu ifade edilmiştir ${ }^{94}$.

Bunun dışında, aynı regülasyonun 53'üncü maddesine göre ihraççı, faaliyet alanı içerisinde fiyatlama ile ilgili vakıalar ${ }^{95}$ hakkında piyasaya bilgi verme yükümü altındadır. Bu bilgilerin gerçeğe aykırı olması halinde de şirket hakkında yanlış bilgi verme suçu oluşur ${ }^{96}$.

Hukukumuzda, benzer düzenlemelere SPKn'de yer verilmiştir. Örneğin SPKn m.14'e göre ihraççı, kamuya açıklanacak finansal tablo ${ }^{97}$ ve raporları, zamanında, tam ve doğru bir şekilde hazırlamak zorundadır. Buna yönelik olarak maddede, "finansal tablo ve raporların hazırlanmasından, sunulmasından ve gerçeğe uygunluğu ile doğruluğundan ihraççı ile kusurlarına ve durumun gereklerine göre ihraççının yönetim kurulu üyeleri sorumludur" denilerek doğru ve gerçeğe uygun tablo ve rapor yükümlülügünün kime ait olduğu açıkça belirlenmiştir. Ayrıca finansal tablo ve raporlarla ilgili olarak bunları hazırlayan ortaklık yöneticileri ile birlikte sorumlu yönetim kurulu üyelerinin kamuya yapacakları bildirimlerde, finansal tablo ve raporların gerçeğe uygunluğu ve doğruluğu konusundaki beyanlarına yer verilmesi de zorunlu tutulmuştur" 98 . SPKn m.112/2'de, "finansal tablo ve raporları gerçeği yansıtmayan şekilde düzenleyenler" ve "kayıtlarda her türlü muhasebe hilesi yapanların" TCK’nın ilgili hükümlerine göre cezalandırılacağı belirtilmiştir. Bu kapsamdaki sorumluluğun, TCK m.164'e göre gündeme geleceği söylenebilir ${ }^{99}$.

Keza SPKn m.15/1'de, sermaye piyasası araçlarının değerini, fiyatını veya yatırımcıların yatırım kararlarını etkileyebilecek nitelikteki bilgi, olay ve gelişmelerin, ihraççılarca veya ilgili taraflarca

94 Schleiffer/Reinwald, s.404; Weber/Baumann, s.82.

95 Bunlar, piyasa fiyatlarında değişikliğe neden olabilecek öneme sahip olmalıdır (KR. Art. 53/1).

96 Lanz/Ryser, s.27.

97 "Bir işletmenin faaliyet ve sonuçları ile doğrudan ilgili olan kesim sadece o işletmenin sahip veya ortakları değildir. Işsetmelerle doğrudan ilgili olan işletme sahip veya ortaklarının yanı sıra o işletme ile ticari, mali ve ekonomik ilişkiler kuran işletmeler veya toplum bireyleri, kredi, finans ve yatırım kuruluşları ile çeşitli kamu kurum ve kuruluşları işletmenin faaliyet ve sonuçları ile ilgilenmekte ve bu konuda sağlıkl ve güvenilir bilgi sahibi olmak istemektedirler. İsletmelerin faaliyet ve sonuçları konusunda bilgi kaynağı ise o işletmenin muhasebe kayıt ve belgeleri ile bunlara dayanılarak hazırlanmış mali tablolardır. Muhasebe bilgilerinin sunulduğu mali tablolara dayanılarak karar alma durumunda bulunan ilgililerin karar almalarında en önemli etken, bu bilgilerin sağliklı ve mukayese edilebilir nitelikte olmasıdır. Makro açıdan milli gelir hesapları ve benzeri istatistiklerin çıkarılmasında, kalkınma planlarının hazırlanmasında, ulusal ve uluslararası sermaye hareketlerinin düzenlenmesinde, ekonomik faaliyetlerin Devlet tarafindan kontrol edilmesi ve yönetilmesinde muhasebede tekdüzeliğin sağlanması büyük önem arz etmektedir. Kaldı ki, mali tablolar aracıllğı ile ilgililere sunulan bilgilerin denetlenmesinin gerekli olduğu hallerde, tekdüzen hesap planı uygulamasının denetimin iş yükünü azaltacă̆ ve kolaylaştıracağı da açıktır." (Maliye ve Gümrük Bakanlığı 1 No' lu Muhasebe Sistemi Uygulama Genel Tebliği, - IIIDüzenlemenin Niteliği-, Resmi Gazete No:21447/Mükerrer, Resmi Gazete Tarihi: 26.12.1992, https://www.resmigazete. gov.tr/arsiv/21447_1.pdf, erişim tarihi: 17.10.2020)

98 Finansal tablo ve raporlarda gerçeğe aykırılığın, dönemsel süreklilik arz eden açıklamalar kapsamında nitelendirilmesine ilişkin bkz. Dursun, Gerçeğe Aykırılıktan Doğan Suçlar, s.218.

99 SPKn m.112/3’te, özel belgede sahtecilik suçundan dolayı cezaya hükmedebilmek için, sahte belgenin kullanılmış olması şartı aranmayacağı ifade edildiğinden, bu durumda ayrıca özel belgede sahtecilik suçundan da sorumluluk söz konusu olacaktır. 
kamuya açıklanması öngörülmüştür. Bu çerçevede öngörülen yükümlülüklere aykırı olarak kamuya yapılan beyanlarda gerçeğe aykırı bilgiler paylaşılmas ${ }^{100}$, TCK m.164'te yer verilen suçu oluşturur. Örneğin işletmelerin varlıklarını, kaynaklarını ve borçlarını gösteren finansal tablolarda, şirketin mali yapısında meydana gelen değişiklikler yanlış bildirilebilir. Ticari alacaklarla ilgili gerekli yasal işlemler yapılmamasına rağmen, bu konuda yanlış bilgi verilmesiyle şirketin iyi bir alacak yönetim politikasına sahip olduğu gösterilmeye çalışılabilir. Şirketin mevcut varlıklarını kiralama yoluyla tekrar mali/finansal tablolarında göstermesi de söz konusu olabilir ${ }^{101}$. Bu gibi hallerde, açılanan bilgiler olguyu tam olarak temsil etmediği için finansal tablolarda kamuya yanlış bilgi sunulması söz konusudur. Ancak daha önce ifade ettiğimiz üzere, tüm bu hususlarda yanlış kabul edilemeyecek eksik bilgi verilmesi yahut aydınlatma yükümüne aykırı olarak bilgi verilmemesi, TCK m.164 kapsamında değerlendirilemez. Çünkü maddede, gerçeğe aykırı bilgi verme veya verdirtme suç olarak kabul edilmiştir.

Düşüncemize göre, şirketle ilgili bilgi verme yükümlülügü altında olan kişilerce eksik bilgi verilmesi veya hiç bilgi verilmemesinin de hükmün kapsamına alınması yerinde olacaktır. Nitekim mehaz İsviçre Ceza Kanunu m.152'de eksik bilgi verilmesi de bu suç yönünden tipik bir davranış olarak kabul edilmiştir.

Belirtmek gerekir ki SPKn’ye tabi bir şirketin yönetim kurulu üyelerince, gerçekleştirilen önemli bir yönetim işlemi hakkında şirket genel kuruluna kasıtlı olarak yanlış bildirimde bulunulmakla birlikte, burada yer alan bilgilerin BISTECH aracilığıyla elektronik raporlama platformunda yayınlanması durumunda hem kamuya hem de genel kurula yanlış bilgi verme gündeme gelecektir ${ }^{102}$. Bu kapsamda, genel kurula verilen bilgi ve kamuya yapılan paylaşımdan hangisi önceyse, suçun işlenme zamanını buna göre belirlemek gerekir.

\section{bb. Genel Kurula Rapor veya Öneri Sunulması}

Bu suçta, fiile ilişkin olup gerçeğe aykırı bilginin veriliş biçimine dair bir özellik olarak düzenlenen diğer husus, söz konusu bilginin, genel kurula sunulan rapor veya önerilerde yer almasıdır. Gerçeğe aykırı bilginin, genel kurul dışındaki bir organa yahut mercie sunulması durumunda, fiil tipik değildir ${ }^{103}$.

100 Kamunun aydınlatılmasında özel durumlar başlı̆̆ı altında düzenlenen bu durumlarda verilen bilgilerin, dönemsel olmayan, özel duruma bağlı sürekliliğe sahip açıklamalar kapsamında nitelendirilmesine ilişkin bkz. Dursun, Gerçeğe Aykırllıktan Doğan Suçlar, s.219.

101 Bunların, tam açıklama yükümlülüğüne aykırılığına ilişkin bkz. Duman, s.110.

102 Schleiffer/Reinwald, s.405.

103 “Sanı̆̆ın, ... Yatırım Holding Anonim Şirketi’nin ortağı ve yönetim kurulu başkanı olduğu, şirketin borcu nedeniyle başlatılan icra takibinin kesinleşmesi nedeniyle haciz işlemi için şirkete giden icra memuruna sanık tarafindan şirketin bir ay önce ... isimli kişiye devredildiğinin belirtildiği, bu beyanin haciz tutanağına yazılarak haciz işlemine son verildiği ancak sanığın şirketi devretmemesine rağmen haciz işleminden kurtulmak amacıyla şirket veya kooperatifler hakkında yanlş bilgi ve resmi belgenin düzenlenmesinde yalan beyan suçların işlediğinin iddia edildiği olayda; Ticaret Sicil Müdürlüğünün yazısı ile sabit olduğu haliyle, sanığın şirketi devretmediği ancak 5237 sayll TCK'nın 164. maddesi gereğince suç oluşabilmesi için, kamuya yapılan beyanlarda veya genel kurula sunulan raporlarda gerçeğe aykırı bilgi verilmesi gerektiği..." (Yargitay 15. CD., 11.11.2019, 2017/30885 E., 2019/11393 K.) 
Daha önce ifade edildiği üzere, kooperatifin arsasının kamulaştırma yahut kentsel dönüşüm kapsamına alınmadığı veya kooperatif ya da şirket hakkında ikame edilmiş bir dava veya başlatılmış olan bir icra takibinin mevcut olmadığına dair bilginin, gerçeğe aykırı olarak genel kurula sunulması bu suçu oluşturur ${ }^{104}$. Keza TTK'da yer verilen, hâkim şirketin her pay sahibinin genel kurulda, bağlı şirketlerin finansal ve malvarlığıyla ilgili durumları ile hesap sonuçları, hâkim şirketin bağlı şirketlerle, bağlı şirketlerin birbirleriyle, hâkim ve bağlı şirketlerin pay sahipleri, yöneticileri ve bunların yakınlarıyla ilişkileri, yaptıkları işlemler ve bunların sonuçları hakkında, özenli, gerçeği aynen ve dürüstçe yansitan hesap verme ilkelerine uygun, doyurucu bilgi verilmesini talep hakkına ilişkin düzenleme (TTK m.200) ve bağlı ve hakim şirketlerde rapor düzenlenmesine ilişkin TTK m.199'da yer verilen hükümler uyarınca, yönetim kurulunca hazırlanan ve genel kurula sunulan raporlarda gerçeğe aykırı bilgiler bulunması durumunda da TCK m.164'te tanımlanan suç oluşur.

Genel kurula gerçeğe aykırı bilgi verilmesinin en tipik örneklerinden bir tanesi, madde gerekçesinde de belirtildiği üzere, gerçeğe aykırı bilançoların sunulmasıdır. Bir ticari işletme, ticari faaliyetinin başında ve her faaliyet döneminin sonunda, varlık ve borçlarının ilişkisini gösteren finansal tabloyu (sırasıyla açılış bilançosunu ve yıllık bilançoyu) çıkarmak zorundadır (TTK m.68/1). Bilanço ile gelir tablosu, yıl sonu finansal tablolarını oluşturur (TTK m.68/3). Aksine kanuni hükümler ve Türkiye Muhasebe Standartları saklı kalmak kaydıyla, finansal tabloların, ticari işletmenin tüm varlıklarını, borçlarını, peşin ödenen giderler ile peşin tahsil edilen gelirleri, teknik terimle dönem ayırıcı hesapları, bütün gelir ve giderleri doğru şekilde değerlendirilmiş olarak göstermesi zorunludur (TTK m.72/1).

Söz konusu düzenlemelerden çıkan sonuca göre, şirket yönetim kurulu tarafından düzenlenen mali/ finansal tablolar, gerçeğe uygun ve denetime elverişli olmalıdır. Görüldüğü gibi, yönetim kurulu üyeleri açısından finansal tabloların oluşturulması, TTK uyarınca bir görev mahiyetindedir. Bunların gerçeğe aykırılık taşıması durumunda, diğer şartların da varlığı halinde ilgili yönetim kurulu üyesi/ üyelerinin TCK m.164'e göre ceza sorumluluğu gündeme gelecektir.

\section{Suçun Konusu}

Bir görüşe göre TCK m.164’te yer verilen suçun konusunu, mağdura ait malvarlığg değerleri oluşturmaktadır ${ }^{105}$. Bununla birlikte yargı kararlarında ${ }^{106}$, suçun konusunun, kamuya yapılan

104 Önceki açılamalarımızda değindiğimiz üzere, bu konularda genel kurula bilgi verilmemesi halinde fiil tipik değildir. Zira kanun koyucu, bilgi vermemeyi değil, yanlış bilgi vermeyi cezalandırmıştır.

105 Artuç, s.880; Bayraktar ve diğer yazarlar, s.413.

106 “TCK 164. maddesinde yer alan suçun konusunu kamuya yapılan yalan beyanlar ile ilgilileri zarara uğratacak şekilde genel kurula sunulan raporların oluşturduğu; bu kapsamda, kamuya yapılan beyanların basın ve yayın yoluyla veya postayla prospektüsler gönderilerek, belirli olmayan kişilere hitap edilmesi şeklinde işlenmiş olabileceği gibi bu tür gerçeğe aykırı önemli bilgilerin genel kurula sunulan raporlarda ya da önerilerde "Gerçeğe uymayan bilançolar yapılması, gerçeğe aykırı karlardan bahsedilmesi biçiminde de işlenmiş olabileceği, ancak bütün bunların, yapılan açıklamanın sunulan raporların veya önerilerin gerçeğe aykırı olduğu bilinerek aldatma kastıyla doğruymuş gibi gösterilmesi ve buna dayalı olarak şirket ya da kooperatifle ilgili bir başkasının iktisadi menfaatinin zarara uğramış veya en azından zarara uğrama tehlikesiyle karşı karşıya kalmış olması zorunludur." (Yargıtay 15. CD., 7.11.2016, 2014/2451 E., 2016/8391 K.) 
beyanlar ile ilgilileri zarara uğratacak şekilde sunulan rapor veya önerilerde yer alan bilgilerden ibaret bulunduğu ifade edilmiştir.

Suçun konusu, tipik hareketin üzerinde işlendiği kişi yahut şeydir ${ }^{107}$. Bu bakımdan öncelikle, maddede yer verilen tipik hareketin konusunun, ilgili kişilerin malvarlı̆̆ olduğunu söylemek mümkün değildir. Zira maddede cezalandırılan fiilin bazı özelliklere sahip olması durumunda, ilgililerin bu bilgiye göre nasıl tasarrufta bulunacaklarına itibar edilmeksizin, failin cezalandırılması öngörülmüştür. Yukarıda, korunan hukuki değer ve suç tipinin mevzuattaki yerine dair yapılan değerlendirmeler bakımından tekrara düşmemek adına, burada yalnızca, madde gerekçesinde korunan hukuki değere atfen yer verilen, "şirket veya kooperatiflerin idaresinde duyulan güven" ibaresinin de bu konuda bir yorum aracı olarak kullanılabileceğine atıf yapmakla yetiniyoruz $^{108}$.

Failin şirket veya kooperatife ilişkin gerçeğe aykırı bilgi de suçun konusu değil, yukarıda izah edildiği üzere, soyut tipte tarif edilen fiile ilişkin bir özelliktir. TCK m.164'te, fail tarafından verilen veya verdirtilen bilginin hangi konuyu kapsadığı hususunda bir belirleme yapılmamıștır. Bu yönüyle söz konusu suç tipi, SPKn m.107/2'de düzenlenen bilgiye dayalı piyasa dolandırıcılığı suçuyla benzerlik gösterir. Nitekim anılan suç açısından da kanun koyucu, tipik harekete matuf olarak sermaye piyasası araçlarının fiyatlarını, değerlerini veya yatırımcıların kararlarını etkilemek amacıyla yalan, yanlış veya yanıltıcı bilgi verme, söylenti çıkarma, haber verme, yorum yapma veya rapor hazırlama ya da bunları yaymadan bahsetmekle yetinmiş, hareketin konusuna dair herhangi bir tespitte bulunmamıştır ${ }^{109}$.

Bununla birlikte, şirket veya kooperatifler hakkında verilen veya verdirtilen gerçeğe aykırı bilginin, ilgilileri malvarlığı açısından zarara uğratabilecek bir öneme sahip olması gerektiğine ilişkin maddede yer verilen ifade, suçun konusuna ilişkin genel bir çerçeve ortaya koymaktadır. Dolayısıyla, bilginin şirket veya kooperatifler ile ilgili kapsadığı konu böylece belirlenebilir. Örneğin, TTK’nın genel kurul toplantıları hakkındaki 409'uncu maddesi uyarınca, yönetim kurulu yıllık raporu veya diğer hususlara ilişkin rapor veya önerilerde, şirketin mali durumuna ilişkin gerçeğe aykırı kar veya zarardan söz edilmesi halinde, suçun konusunu buna göre belirlemek mümkündür. Keza şirket veya kooperatif genel kuruluna, genel kurul toplantısı esnasında veya toplantı öncesinde, geçmiş dönemlere ilişkin raporlarda veya mevcut durum esas alınarak yapılan geleceğe yönelik istek ve tekliflerde yanlış bilgi verilmesi halinde, genel kurula sunulan rapor ve önerilerde gerçeğe aykırı bilgi verilmesi söz konusudur. Madde gerekçesinde, yanlış bilgiye örnek olarak gerçeğe uymayan bilançolar yapılması ${ }^{110}$, gerçeğe aykırı kardan bahsedilmesi gösterilmiştir.

107 KOCA, Mahmut/ÜZÜLMEZ, İlhan, Türk Ceza Hukuku Genel Hükümler, 11. Baskı, Seçkin, Ankara, 2018, s.118; ÖZBEK, Veli Özer/BACAKSIZ, Pınar/DOĞAN, Koray/TEPE, İlker, Türk Ceza Hukuku Genel Hükümler, 9. Baskı, Seçkin, Ankara, 2018, s.211.

108 Ekonomik suçlarda, suçun konusunun tespitinin genellikle zor olduğu hususunda bkz. Küçüktaşdemir, s.122.

109 Dursun, Gerçeğe Aykırılıktan Doğan Suçlar, s.311.

110 Yargıtay 15. CD’nnin, 7.11.2016, 2014/2451 E., 2016/8391 K. sayılı ilamında da gerçeğe aykırı bilanço yapılmasının bu suç kapsamında kabul edilebileceğine işaret edilmiştir. İsviçre Federal Mahkemesi’nin 6B_25/2008 sayıll, 9.10.2008 tarihli kararında da gerçeğe aykırı bilanço ve finansal tablolar hazırlanması, tipik davranışlar olarak kabul edilmiştir. (www. bger.ch, erişim tarihi: 18.10 .2020$)$ 


\section{Fail}

Suçun faili, bir şirket yahut kooperatifin, ortak, idareci, müdür veya temsilcileri veya yönetim veya denetim kurulu üyeleri veya tasfiye memuru sıfatını taşıyan kişiler olabilir ${ }^{111}$. Bu yönüyle TCK m.164'te düzenlenen suç tipi, ekonomik suçların genelinde müşahede edildiği üzere ${ }^{112}$ özgü suç özelliği taşımaktadır ${ }^{113}$. Bu kapsamda, maddede belirtilen sıfatları haiz olanların belirlenmesinde, Türk Ticaret Kanunu ve Kooperatifler Kanunu hükümleri çerçevesinde, şirket veya kooperatifin yönetim-organizasyona ilişkin yapısı nazarı itibara alınacaktır ${ }^{114}$. Örneğin, TTK m.370 vd. hükümlerine göre anonim şirketlerde yönetim kurulu üyeleri, şirketi temsil etme yetkisini, bir murahhas üyeye ya da müdür olarak üçüncü kişiye devretmişlerse, bu kişi suçun faili olabilir.

Maddede düzenlenen seçimlik hareketler yönünden fail, gerçeğe aykırı önemli bilgiyi kendisi verebileceği gibi, örneğin şirkette çalışan bir başkasına da verdirtebilir ${ }^{115}$. Zira maddede, gerçeğe aykırı önemli bilginin verilmesi yanında, verdirtilmesi de tipik bir davranış olarak kabul edilmiştir. Dolayısıyla, bilgiyi veren ve verdirten kişiler, bu bilginin gerçeğe aykırı oluşturulması ve sunulması görev ve yetkisine sahip olup maddede belirtilen sıfatları taşıyorlarsa, bunlardan her birinin fail olduğu sonucuna ulaşılmalıdır.

İsviçre hukukunda, İsviçre Ceza Kanunu m.29'da yer verilen özel düzenleme dolayısıyla ${ }^{116}$, maddede sayılan kişilerden olmasa dahi şirket iradesinin oluşumunda belirleyici olan kişiler de (fiili organ) $)^{117}$

111 Bu sıfatı taşımayan kişiler söz konusu suçun faili olamazlar. Nitekim Yargıtay 15. CD.'nin 2.7.2020 tarih ve 2017/31008 E., 2020/7348 K. sayılı ilamında, “... Katılan ...’in S.S. ... Konut Yapı Kooperatifi Başkanı olduğu, sanığın da bu kooperatifte üye olduğu, 30/06/2013 tarihinde gerçekleşmiş genel kurulda sanığın kooperatif başkanlı̆̆ına aday olduğu, adaylık süreci içerisinde dağıtmış olduğu el ilanında “...başkan biz üyeleri hep ahmak yerine koymaktadır.... başkanın doğru söylediğini hiç görmedim... sizlere çok miktarda delil ve yolsuzluk belgesi sundum.... isteyene gelsin elden de veririm, bu kooperatif çok uzadı, üyeler perişan oldu....” şeklinde kooperatif ile ilgili olarak gerçeğe aykırı bilgiler verdiği iddia edilen olayda; Şirket veya kooperatif hakkında yanlış bilgi vermek suçunun oluşabilmesi için kooperatif hakkında kooperatifin kurucusu, ortak, idareci, müdür veya temsilcilerin veya yönetim veya denetim kurulu üyeleri veya tasfiye memuru sıfatını taşıyan kişilerin kamuya yaptıkları beyanlar veya genel kurula sundukları rapor ya da öneriler aracılı̆̆ıla ilgililerin zarara uğramasına sebep olacak nitelikte gerçeğe aykırı kasten yanlış bilgi verilmesi veya verdirtilmesi... gerekir" denilerek kooperatif üyesinin bu suçun faili olamayacağı belirtilmiştir.

112 İstisnaları bulunmak kaydıyla, ekonomik suçların genel itibarıyla gerçek özgü suçlar olduğu hususunda bkz. Tiedemann/ Engelhart, kn.215; WITTIG, Petra, Wirtschaftsstrafrecht, 5. Auflage, C.H Beck, München, 2020, s.38; Aytekinİnceoğlu, s.11.

113 WEISSENBERGER, Philippe, Art. 152 StGB, in: Basler Kommentar, Strafrecht II, Art. 111-392 StGB, 2. Auflage, Basel 2007, kn.4; Schlegel, kn.2; Donatsch, Art. 152, s.375, kn.2; Schmid, s.7.

114 Lanz/Ryser, s.29. Kooperatifler Kanunu'nun Ek Madde 2/son hükmü gereğince, ilgili Bakanlık, kooperatifler ve üst kuruluşlarının yönetim ve denetim kurulu üyeleri ile memurları hakkında görevlerine ilişkin olarak işledikleri suçlardan dolayı açılan kamu davalarına katılma talebinde bulunma hakkına sahiptir: “... CMK’nın 234/1-b maddesi gereğince kovuşturma evresinde sahip oldukları davaya katılma ve öteki haklarını kullanabilmeleri için Maliye Bakanlığı Baş Hukuk Müşavirliği ve Muhakemat Genel Müdürlüğü ile Çevre ve Şehircilik Bakanlı̆̆ının dava ve duruşmalardan haberdar edilmeleri gerekir..." (Yargitay 5. CD., 10.1.2019, 2018/6442 E., 2019/334 K.). TCK m. 164'ün gerekçesinde, maddede yer alan düzenlemenin sermayesi hisse senedine bölünmüş kamu iktisadi teşebbüslerinde de uygulanacağı belirtilmiştir. Bu çerçevede, kamu iktisadi teşebbüsleri bakımından fail sıfatını haiz olabilecekler 233 sayılı Kamu İktisadi Teşebbüsleri Hakkında Kanun Hükmünde Kararname düzenlemeleri çerçevesinde saptanmalıdır (Bayraktar ve diğer yazarlar, s.412).

115 Schlegel, kn.3

116 Söz konusu düzenlemeye göre, tüzel kişiliği haiz bir şirkete veya adi şirkete ait bir yükümlülük kapsamında gerçekleştirilen ve suç teşkil eden davranışlardan, o şirketin organlarından birinin üyesi veya şirketin çalışanı olmasa da fiili olarak şirketin yönetimine tesir eden kişinin sorumlu tutulması mümkündür.

117 Şirket idaresindeki etkileri nedeniyle bu kişilerin maddi anlamda organ teorisine göre hukuki sorumluluk altında 
fail olarak kabul edilmiştir ${ }^{118}$. Bu doğrultuda İsviçre Federal Yüksek Mahkemesi konuyla ilgili bir kararında ${ }^{119}$, bir tröst şirketin kuruluşunda, inançlı üye ${ }^{120}$ ile sermayenin kısa sürede ödenmesi için gerekli olan fonları kendisine sağlayacağı hususunda anlaşmaya vardığı belirlenen kişi, her ne kadar resmi sıfatı itibarılya failde aranan özellikleri taşımasa da şirketin idaresinde fiili olarak yer aldığ 1 ve sermaye ile ilgili olarak gerçeğe aykırı bilgi verilmesini sağladığı gerekçesiyle, fail olarak kabul edilmiştir. Mahkemeye göre, şirket ile iş ilişkisine girmek isteyen üçüncü kişiler, kuruluş anında uygun varlıklara sahip şirkete güvenirler. Sermaye konusunda yanlış bilgi, iflas riskinin farkında olmayan üçüncü şahısları, yatırım aracı olarak kullandıkları varlıklara zarar verecek tasarruflar yapmaya ikna etmeye elverişli olduğundan, bilgi, anılan suç bakımından aranan önemi haizdir.

Ticaret hukukunda, fiili organ teorisine göre maddi anlamda organ olarak kabul edilen kişilerin, hukukumuz açısından da fail olarak sorumlu tutulmasının mümkün olduğu kanaatindeyiz.

Burada, inançlı yönetim kurulu üyesi açısından özel hukuk nezdinde yapılan ikili ayrıma da değinmek gerekir. İlk grup, bilgi ve eğitim düzeyi yüksek, toplumda bir yer kazanmış ve bu nedenle yönetim kuruluna seçilmiş kimselerdir ki, böylece şirket dışarıya karşı itibar kazanmakta, daha fazla güven telkin etmektedir. Buna karşılık ikinci grup, bu göreve kendi iradeleriyle değil, şirketin arkasında bulunan sermaye sahibinin (fiili organ) baskısılla getirilen, çoğu zaman aynı şirkette hizmet akdiyle başka bir görevi ifa eden kimselerden oluşur. Yönetim için gerekli bilgi donanımına sahip olmayan, hatta kendisine yüklenen görev ve yetkinin ne anlama geldiğini bilmeyen ama şeklen bu görevi yerine getiren bu ikinci grubun, şeklen yönetim kurulu üyesi olsalar da fiilen organ sıfatını taşımadıklarından, yönetim kurulu üyesi sıfatından kaynaklanan özel hukuk sorumluluğundan bağışık tutulmaları gerektiği ifade edilmiştir ${ }^{121}$.

Hukukumuz bakımından, bilgiyi veren ve şekli anlamda organ olarak kabul edilen ${ }^{122}$ ilk grup inançlı yönetim kurulu üyesi, görevi üstlenmekle, üçüncü kişiler nezdinde şirketi iyi bir şekilde idare edeceği yönünde intiba uyandırmaktadır ${ }^{123}$. Bu bakımdan ilk grup inançlı yönetim kurulu üyesinin, gerçeğe aykırı bilgi nedeniyle TCK m.164'te düzenlenen suçun faili olarak sorumlu tutulacağı söylenebilir. Zira inançlı üye, inanana (fiili organ) karşı, yönetim kurulunda belirli şekilde hareket edeceği ya da onların talimatlarına tabi olacağı şeklinde sözleşmesel bir yükümlülük altına girmekteyse de bu yükümlülük, yalnızca hukuka uygun işlemlere yönelik olarak bağlayıcıdır.

oldukları hususunda bkz. FORSTMOSER, Peter, Der Organbegriff im aktienrechtlichen Verantwortlichkeitsrecht, in: Forstmoser/Schluep (Hrsg.), Freiheit und Verantwortung im Recht, Festschrift zum 60. Geburtstag von Arthur MeierHayoz (Bern 1982), s.129.

118 Weissenberger (Basler Kommentar StGB II), kn. 7; Donatsch, Art. 152, s.375, kn.2; Schmid, s.7.

119 6B_230/2011 11.08.2011 (www.bger.ch, erişim tarihi: 18.10.2020)

120 İnançlı yönetim kurulu üyesi, olağan seçim kuralları ile yönetim kuruluna hukuka uygun şekilde seçilmiş olan fakat üçüncü kişiye, yani inanana karşı yönetim kurulunda belirli şekilde hareket edeceği ya da onların talimatlarına tabi olacağı şeklinde sözleşmesel yükümlülük altına giren yönetim kurulu üyeleridir (AKDAĞ GÜNEY, Necla, Anonim Şirket Yönetim Kurulu, 2. Baskı, Vedat, İstanbul, 2016, s.325).

121 Bkz. Akdă̆-Güney, s.325, 326.

122 Bkz. Forstmoser, s.129.

123 Akdağ-Güney, s.325. 
İkinci grup inançlı üye açısından, özel hukuk sorumluluğuna ilişkin yukarıda zikredilen düşünce, ceza hukuku yönünden, ikinci gruptaki inançlı üyenin, yönetim kurulu üyesi olması ve fiili organın talimatları doğrultusunda hareket etmesine ilişkin iradesinin baskı altında bulunup bulunmadığı dikkate alınarak değerlendirilmelidir. Diğer bir ifadeyle, şayet inançlı üye yönünden mazeret nedeni oluşturabilecek bir zorlama mevcutsa (TCK m.28), bu kişinin ceza sorumluluğu yoktur. Söz gelimi, şirkette genellikle hizmet akdiyle başkaca bir görev ifa eden bu kişiler, işlerinden edilmekle tehdit edilmiş olabilir. TCK m.28’e göre, tehdidin mazeret nedeni olarak kabul edilebilmesi için muhakkak ve ağır olması gerektiğine işaret edilmiştir. Tehdidin ağırlı̆̆ı, ciddiliği ile ilgili bir konudur. Tehdidin mazeret nedeni olarak kabul edilmesinde, somut olayın özellikleri dikkate alınmalıdır. Bu itibarla verdiğimiz örnekte işinin elinden alınacağ fiili organın şirketteki etkinliği, inançlı üyenin hizmet akdiyle çalıştığı işini kaybetmesine neden olabilir.

\section{Mağdur}

Ekonomik suçların en önemli özelliklerinden biri de muhtemel mağdurların sayısının çok oluşudur. Ekonomik suçlar, ekonomik düzenin güven içerisinde işlemesini tehlikeye sokan davranışlarla işlendiğinden, esasen bu tür suçların işlenmesiyle, o ekonomik düzene tabi olan herkesin dolaylı olarak zarar görmesi ihtimali mevcuttur. Ayrıca söz konusu suçlardan doğrudan doğruya zarar gören mağdurların sayısı da genelde bir hayli fazladır ${ }^{124}$.

Ekonomik suçların genelinde müşahede edildiği üzere, bu suçta ilgilileri malvarlığı yönünden zarara uğratabilecek, gerçeğe aykırı, önemli bilginin verilmesi anında, yani suçun işlendiği sırada, ortada müşahhas bir mağdur yoktur ${ }^{125}$. Dolayısıyla, suçun oluşması için gerekli olmamakla birlikte, işlenen fiil nedeniyle ve suçun işlenmesinden sonra, bazı kişilerin malvarlıklarının zarara uğradığının belirlenmiş olması, bu hususu değiştirmez. Bu çerçevede, suçun konusunun, doğrudan ve belli bir mağdura ait bir malvarlığı değeri olmadığı ve işlenen fiilin de belli bir kişinin menfaatine yönelmediği de dikkate alınarak bu suçta, zilyedin yahut mülkiyet hakkı sahibinin teknik ve dar anlamda suçun mağduru olduğu - malvarlığına karşı suçlarda olduğu gibi - söylenemez. Dolayısıyla bu suçun, mağduru belli olmayan, kamuya karşı işlenen bir suç olarak kabul edilmesi kaçınılmazdır ${ }^{126}$. Bu husus, suç tipinin malvarlığına karşı suçlar içerisinde düzenlenmesinin doğru bir tercih olmadığının başka bir göstergesidir.

\section{B. Manevi Unsur}

Bu suçun manevi unsuru kasttır ${ }^{127}$. Maddede, gerçeğe aykırı bilginin sunulmasıyla bir zarar tehlikesinin ortaya çıkmasına yönelik özel bir amaçla hareket edilmesi aranmamıştır. Fail, sunulan

124 Aytekin-İnceoğlu, s.14; Küçüktaşdemir, s.117 vd.

125 Trafik güvenliğini tehlikeye düşürme gibi, korunan hukuki menfaatin belli bir kişiye ait olmadığı suçlarda, suçun özel bir mağdurunun bulunmadığı hususunda ayrıca bkz. ÖZTÜRK, Bahri/ERDEM, Mustafa Ruhan, Uygulamalı Ceza Hukuku ve Güvenlik Tedbirleri Hukuku, Seçkin, Ankara, 2018, s.192.

126 Zincirleme suç hükümlerinin de bu kapsamda TCK m.43/1'e göre değerlendirilmesi gerekir.

127 Yargitay 15. CD., 7.11.2016, 2014/2451 E., 2016/8391 K. 
raporların veya önerilerin gerçeğe aykırı olduğunu bilerek bunlar doğruymuş gibi gösterirse suç oluşur $^{128}$. Bu bakımdan örneğin, muhasebe kayıt usullerine aykırı hazırlanan bilançodaki bilgiler gerçekle uyuşmasa dahi söz konusu gerçeğe aykırılık hataya dayalıysa, suç oluşmayacaktır ${ }^{129}$. Fail, bilginin gerçeğe aykırılı̆̆ı hususunda tereddüt etmekle birlikte, bu bilgiyi genel kurula sunar yahut kamuyla paylaşırsa, suçun olası kastla işlendiği kabul edilmelidir.

\section{Hukuka Aykırılık Unsuru}

Bir suçta tipik fiilin gerçekleştirilmesi, hukuka aykırılığın mevcudiyetine karine oluşturur. Şayet somut olayda herhangi bir hukuka uygunluk nedeni yoksa, işlenen fiil hukuka aykırıdır. Bu suç bakımından da durum aynıdır; herhangi bir hukuka uygunluk nedeninin mevcut olması, fiili hukuka uygun kılar. Bununla birlikte, bu suçun yapısı dikkate alındığında, hakkın kullanılması hukuka uygunluk nedeninin bazı yönlerden önem arz ettiği söylenebilir.

Düşünceyi açıklama ve yayma hürriyeti içerisinde yer alan haber verme hakk1 ${ }^{130}$ ile bağlantılı olarak $^{131}$ basın özgürlüğ̈̈ ${ }^{132}$, özellikle şirket veya kooperatifle ilgili gerçeğe aykırı bilginin basın ${ }^{133}$ yoluyla kamuya duyurulması çerçevesinde bir hukuka uygunluk nedeni (hakkın kullanılması) olarak tartışılabilir. Anayasanın basın özgürlüğünü düzenleyen 28'inci maddesi, bu özgürlüğün sinırlandırılmasında 26 'ncı ve 27'nci maddelere atıfta bulunarak kamu düzeninin, dolayısıyla bu düzenin bir parçası olduğunu vurguladığımız ekonomik düzenin ve başkalarının haklarının korunması amacıyla ${ }^{134}$ basın özgürlüğünün sınırlandırılmasına müsaade etmiştir. Bu bakımdan, TCK m.164’te suç olarak tanımlanan eylemlerin, basının haber verme özgürlügü kapsamında kabul edilemeyeceğinde şüphe yoktur. Dolayısıyla, verilen haberin gerçeğe aykırılığı, haberi veren gazeteci tarafından biliniyorsa, bu kişinin ceza sorumluluğu söz konusu olacaktır ${ }^{135}$. Bu suç yönünden gazeteciler (geniş anlamda basın mensupları), maddede belirtilen fail özelliklerini haiz olmadıkları için suçun faili olamasalar da suça iştirak çerçevesinde cezalandırılabilmeleri mümkündür.

128 Trechsel/Crameri, kn.7 (s.893); Schlegel, kn.5; Jecker, s.217.

129 İsviçre Federal Mahkemesi’nin 6B_577/2010 E. 4.5 sayılı ve 28.2.2011 tarihli kararı (www.bger.ch, erişim tarihi:21.10.2020)

130 ARTUK, Mehmet Emin/GÖKCEN, Ahmet/YENIDÜNYA, A. Caner, Ceza Hukuku Genel Hükümler, 10. Baskı, Adalet, Ankara, 2016, s.433. Bu hak, haberi toplama, yorumlama ve aktarma, haberi yayma şeklinde üç hakkı barındıran torba bir haktır (DÖNMEZER, Sulhi, Basın Hukuku Cilt: 1, Sulhi Garan Matbaası, İstanbul, 1958, s. 61).

131 Haber verme hakkının, basın özgürlüğünün içeriğini oluşturduğu hususunda bkz. AKBULUT, Berrin, Ceza Hukuku Genel Hükümler, 6. Baskı, Adalet, Ankara, 2019, s.514.

132 Haber verme hakkı ve basın özgürlüğü ilişkisi yönünden bkz. BAYINDIR, Sinan/APİş, Özge, Bir Hukuka Uygunluk Nedeni Olarak Haber Verme Hakkının Yazılı Basın Yoluyla İşlenen Hakaret Suçları Açısından Değerlendirilmesi, Türkiye Barolar Birliği Dergisi, Y.2010, S.91, s.90. Gazetecilik mesleğinin icrasının, daha çok haber verme hakkının icrası kapsamında ortaya çıktığı hususunda ayrıca bkz. Özbek/Doğan/Bacaksız/Tepe, s.324.

133 AİHM’nin ifade özgürlüğüne ilişkin kararlarının önemli bir kısmının konusunu basılı eserlere ilişkin düşünce açıklamalarının engellenmesinin oluşturduğu dikkate alınarak basın kavramının, görsel ve işitsel bütün kitle iletişim araçlarını kapsayan bir kavram olmaktan ziyade gazete, dergi, kitap, broşür gibi yalnızca yazılı ve basılı eserleri kapsayan bir manada kullanılmasına yönelik bkz. URAN, Peri, Avrupa İnsan Hakları Mahkemesi ve Türk Anayasa Mahkemesi’nin Basın Özgürlüğüne Yaklaşımı, Türkiye Barolar Birliği Dergisi, Y.105, S.120, s.88.

134 Bunların Basın Kanunu m.3/2'de belirtilen sebeplerle ilişkisi yönünden bkz. Uran, s.92.

135 ÖZGENÇ, İzzet, Türk Ceza Hukuku Genel Hükümler, 14. Bası, Seçkin, Ankara, 2018, s.318. 
Şirket veya kooperatifle ilgili haber niteliği taşıyan bilginin basın yoluyla açıklanmasında, haberi yayınlayan basın mensubunun, bu bilginin doğruluğundan, dolayısıyla da haberin gerçekliğinden kuşku duyması söz konusu olabilir. Bu durumda da konunun, haber verme hakkının hukuka uygunluk nedeni olarak kabul edilebilmesi için gerekli olan "haberin gerçekliği" kriteri çerçevesinde değerlendirilmesi gerekir. Gazeteci, her halükarda haberin veriliş zamanındaki durumu araştırmakla yükümlüdür ${ }^{136}$. Bu araştırma, bir hakim veya savcının yapacağı genişlikte olamayacağına göre, gazeteciye düşen yükümlülük, hiçbir araştırma yapmaksızın ya da somut verilere dayanmaksızın, sadece duyuma dayalı haber yapmamaktan ibarettir ${ }^{137}$. Aksini düşünmek, basın özgürlügünün ölçüsüz sınırlandırılması anlamına gelir ${ }^{138}$. Bu itibarla örneğin, ilgili şirketten bilginin teyit edilmesinin sağlanmasına matuf yolların tüketilmesi gerektiği söylenebilir. Şayet şirketten farklı bir bilgi alınmışsa, haber kaynağıyla tekrar iletişime geçilmesi, haber aktarılırken, "şirket tarafindan teyid edilmeyen bir bilgiye göre" gibi ifadelere yer verilmesi yerinde olacaktır. Aksi durumda, somut olayın özelliklerine göre, bilginin doğruluğu açısından olası kastla hareket edilip edilmediği araştırılmalıdır. Bu noktada elbette, haberi veren kişinin şirketteki konumu da dikkate alınmalıdır. Söz gelimi haber, yönetim kurulu başkanı tarafından verilmişse, bunun şirkette teyit edilmesine ihtiyaç duyulmayabilir.

\section{Suçun Özel Görünüş Biçimleri}

\section{A. Teşebbüs}

Şirket veya kooperatifler hakkında yanlış bilgi verme suçunun oluşumu için zararlı bir neticenin veya somut bir zarar tehlikesinin meydana gelmesinin aranmadığını belirtmiştik. Bu itibarla suç, gerçeğe aykırı bilgi verilmekle tamamlanacaktır. Dolayısıyla, bu suç bakımından teşebbüsten söz edilebilmesi için icra hareketlerinin failin elinde olmayan nedenlerle tamamlanamamış olması gerekir.

Failin, bir şirket veya kooperatifin mali durumuna ilişkin bir belgeyi bir gazeteciye posta ya da elektronik posta aracılığıyla gönderdiği varsayımında, belge kaybolur ya da muhataba ulaşmadan önce belgeye el konulursa yahut da herhangi bir şekilde belge muhatabına ulaşmazsa ${ }^{139}$, suç teşebbüs aşamasında kalmış olacaktır. Keza bir şirket veya kooperatifin kurucu, ortak, idareci, müdür veya temsilcileri veya yönetim veya denetim kurulu üyeleri veya tasfiye memuru sıfatını taşıyanlar, şirket

136 Özbek/Doğan/Bacaksız/Tepe, s.324. Haberin sonradan gerçek olmadığını anlaşılması, haber verme hakkının varlığını etkilemez: "Anayasanın 28. maddesinde ifade edilen basın özgürlüğ̈̈; basının, kamuya ilgilendiren sorunlar hakkında halka bilgi verilmesinde ve bunların tartışılmasındaki genel menfaat esasına dayanır. Basın, kişilerin amme hayatını ilgilendiren eylemlerine ilişkin haberleri gerçeklik, kamu yararı, toplumsal bilgi, güncellik ve konu ile ifade sırasında düşünsel bağlılık kurallarına uygun olarak vermek durumundadır. Doğruluğu veya yanlışlığı hakkında, halin özelliklerine uygun bir araştırma yapmadan gerçeğe aykırı haber yayınlanırsa, haksız bir tecavüz söz konusu olur. Gereken inceleme ve soruşturma yapıldıktan sonra bir haber yayınlanmışsa, sonradan haberin gerçeğe aykırı olduğu anlaşılsa bile haksız tecavüzden söz edilemez." (Yargitay 7. CD., 04.11.1991, 1991/10052 E., 1991/12118 K.)

137 Artuk/Gökcen/Yenidünya, s.434.

138 Bayındır/Apiş, s.93.

139 Belirtmek gerekir ki belgenin muhataba ulaşmaması durumunda, gönderildiğinin tespit edilmesinde ispat zorlukları söz konusu olabilir. 
veya kooperatif hakkında önemli bilgiler açıklayacaklarını belirterek bazı kimseleri bir yere davet ettikten sonra iradeleri dışında açıklamada bulunamazlarsa, teşebbüs söz konusudur ${ }^{140}$.

\section{B. Iştirak}

Fail bahsinde işaret ettiğimiz üzere, şirketler veya kooperatifler hakkında yanlış bilgi verme suçunun faili, yalnızca şirket veya kooperatifin kurucu, ortak, idareci, müdür veya temsilcileri veya yönetim veya denetim kurulu üyeleri veya tasfiye memuru sıfatını taşıyanlar olabilir. TCK m.40/2'de, özgü suçlarda, ancak özel faillik niteliğini taşıyan kişinin fail olabileceği, bu suçların işlenişine iştirak eden diğer kişilerin ise, azmettiren veya yardım eden olabileceği düzenlenmiştir. Bu bakımdan şirket veya kooperatifler hakkında yanlış bilgi verme suçunda, özel faillik niteliğini taşımayan kişinin katkısı azmettiren olarak kabul edilmesine imkan veriyorsa bu kişi azmettiren; bu nitelikte sayılamıyorsa yardım eden olacaktır.

Bunun dışında iştirak bahsinde ilk olarak, maddede tanımlanan sıfata sahip bir kişinin, bu sıfata münhasıran sahip olduğu yetkilerini, hukuka uygun olarak bir başkasına devretmesi ve gerçeğe aykırı bilginin, bu kişi tarafından verilmesi durumunda nasıl hareket edilmesi gerektiğine değinmek gerekir. Söz gelimi bir yönetim kurulu üyesi, TTK m.375’te belirtilenler dışındaki işlemleri, temsilcisi aracılığıyla gerçekleştirebilir ${ }^{141}$. Bu durumda, bazı ülkelerin ceza kanunlarında, söz konusu kişinin fail olarak sorumlu tutulmasına yönelik hükümler sevk edildiği görülmektedir. Örneğin Alman Ceza Kanunu m.14'te, temsilci sıfatıyla hareket etmekle birlikte özgü suçlarda, suçun tanımında öngörülen özellikleri taşımayan kişinin, - temsil olunanın bu özellikleri taşıyor olması şartıyla cezalandırılmasına imkan tanınmıştır. Mevzuatımızda bu yönde bir hüküm bulunmadığından, TCK m.40’ta yer verilen düzenleme kapsamında, bu kişilerin suçun faili olamayacağı, ancak yardım eden olarak işlenen suçtan sorumlu tutulacağı söylenebilir.

Bilgi verdirtme kapsamında, failin talimatıyla gerçeğe aykırı bilgiyi veren kişi, maddede belirtilen sıfatlardan birine sahip olmayıp da sadece bilgiyi aktarıyorsa, bu bilginin gerçeğe aykırı olduğunu bilmesi ve bilginin verilmesinde şirket ilişkilerinden kaynaklanan bir zorunluluk bulunmaması kaydıyla, ancak iştirak hükümlerine göre sorumlu tutulabilir. Buna karşılık maddede tanımlandığ 1 haliyle, bilgiyi verdirten, failde aranan özelliklere sahipse, suçun failidir.

\section{C. İçtima}

Şirket veya kooperatifler hakkında yanlış bilgi verme suçunun zincirleme şekilde işlenmesi mümkündür. Yukarıdaki açıklamalarımız kapsamında, bu suçun teknik ve dar anlamda bir mağdurunun bulunmadığı görüşünde olduğumuzu belirtmiştik. Bu bakımdan, aynı suç işleme kararının icrası kapsamında, birden fazla genel kurulda veya kamuya yapılan beyanlarda farklı gerçeğe

140 Bayraktar ve diğer yazarlar, s.418.

141 Anlaşılacağı üzere burada kastedilen, şirketi temsile yetkili kişiler değildir. Zira bu kişiler, TCK m.164’e göre fail sıfatına sahiptirler. 
aykırı bilgiler verilirse, TCK m.43/1'de yer verilen, mağduru belli olmayan suçlarda da zincirleme suç hükümlerinin uygulanacağına dair düzenleme dikkate alınarak fail hakkında artırılmış tek bir ceza verilmesi gerekir. Burada dikkat edilmesi gereken husus, genel kurul sırasında, daha önceki genel kurulda sunulan gerçeğe aykırı bilginin tekrar edilmesinin, yeni bir suç oluşturmayacağıdır.

Fail tarafından, birden fazla gerçeğe aykırı bilginin tek bir belgeyle aynı genel kurulda sunulması, şirketin internet sitesinde veya kamusal alanlardaki reklam panolarılla ${ }^{142}$ kamuya duyurulması halinde tek bir fiil söz konusu olduğundan, tek suç işlenmiştir. Gerçeğe aykırı bir bilginin, hem genel kurulda sunulması hem de kamuya yapılan duyurularda kullanılması halinde de tek suç söz konusudur.

Bu suçu dolandırıcılıktan ayıran en önemli özellik, hileli davranışlarla failin kendisine veya başkasına bir menfaat sağlamış olmasıdır. Bu bakımdan şayet fail, hileli davranışlarla gerçeğe aykırı önemli bilgilerle bir ticari ilişkiye girerek kendisine veya şirket veya kooperatife yarar sağlarsa, daha ağır ceza öngören dolandırıcılık suçundan cezalandırılmalıdır ${ }^{143}$.

Verilen gerçeğe aykırı bilginin, SPKn m.107/2 çerçevesinde bilgiye dayalı piyasa dolandırıcıllğı suçunu oluşturması halinde ise, SPKn m.107 ile TCK m.164 arasında özel-genel norm ilişkisi bulunmadığından, tek fiille birden fazla kanun hükmünün ihlal edildiği kabul edilmelidir ${ }^{144}$. Kanunumuzda, görünüşte içtima kuralları kapsamında asli-tali norm ilişkisine yönelik bir düzenleme olmadığından, bu halde TCK m.44 kapsamında fikri içtima kuralları uygulanarak, - dolandırıcılıkta olduğu gibi - fail hakkında daha ağır ceza öngören hüküm olan SPKn m.107 uygulanmalıdır.

Belirtmek gerekir ki TTK m.164'e göre gerçeğe aykırı hazırlanan belge ve kayıtlar, mahiyetleri itibarı ile özel belge niteliğindedir. Yargitay 19. CD.'nin, 28.2.2018 tarih, 2017/6538 E., 2018/2202 K. say1l ilamında; "Dava; (6362 sayıl Sermaye Piyasası Kanunu'nun 112 nci maddesinin yollamastyla) Özel belgede sahtecilik suçuna ilişkindir... 22-25/12/2006 döneminde M...nin Denizbank'tan 8.000.000 YTL tutarında spot kredi kullandiktan sonra bu kredinin 2 gün içerisinde grup şirketleri ve Emine Hatice S’nin hesapları arasında dolaştırılması sonucu fiktif muhasebe kayıtlarının olușturulduğu, nakit hareketleri sonucunda gerçeğe aykırn şekilde hesaplarm bakiyelerinin değiştirildiği, bu işlem sonucu M...’nin T... Holding A.Ş. (TTH)'ye gerçeğe aykırı kayıtlarla 18.174.368,40 YTL borçlandırıldiğı..., sanıkların yöneticisi oldukları şirkete ait mali tabloları gerçekleştirdikleri eylemlerle gerçeğe aykırı şekilde düzenledikleri..." denilerek bu türden belgelerin özel belge niteliğinde olduğuna işaret edilmiştir.

Failin açıkladığı gerçeğe aykırı bilgilerin rapor veya önerilerde yer alması ihtimalinde, bunlar içerik yönünden sahte olacaktır. Kanaatimizce TCK m.164’te sahteciliğe açıkça işaret edilmediğinden, maddede düzenlenen suçun belgede sahteciliği içinde barındırdığından bahisle bileşik suçun varlı̆̆ından söz edilemez.

142 Gerçeğe aykırı bilgilerin birden fazla reklam panosunda duyurulması, hareketin hukuki anlamda tekliğini etkilemez.

143 Artuç, s. 883.

144 Dursun, Gerçeğe Aykırılıktan Doğan Suçlar, s. 341. 
Bunun dişında doktrinde, TCK m.212 uyarınca gerçek içtima hükümleri uygulanarak faile hem belgede sahtecilikten hem de TCK m.164 uyarınca ceza verilmesi gerektiği belirtilmişse de ${ }^{145}$ baskın görüşe göre özel belgede sahteciliği düzenleyen TCK m.207 fikri sahteciliği kapsamadığından, yalnızca TCK m.164 uygulama alanı bulabilecektir. Gerçekten kamu görevlisi tarafından işlenen resmi belgede sahtecilik suçundan (TCK m.204/2) farklı olarak TCK m.207'de "gerçeğe aykırı belge düzenlemek" suç olarak düzenlenmemiştir ${ }^{146}$. Dolayısıyla TCK m.164 anlamında, maddi anlamda (şekil olarak) sahte olmayan fakat içeriğindeki bilgiler itibarıyla gerçeğe aykırılık özelliği taşıyan belgelerin TCK m.207'deki suçu oluşturmaları mümkün gözükmemektedir.

Bununla birlikte, TCK m.164'e göre tipik kabul edilen eylemlerin, belgelerin mahiyetine göre, fikri sahteciliği cezalandıran VUK m.359'a göre suç oluşturması mümkündür. Nitekim 213 sayılı Vergi Usul Kanunu’nun, "Kaçakçlık Suçları ve Cezaları” başlıklı 23.1.2008 tarih ve 5728 sayılı Kanun'un 276'ncı maddesiyle değişik 359'uncu maddesinin 1-b bendinde; “... gerçek bir muamele veya durum olmadığı halde bunlar varmış gibi düzenlenen belge, sahte belgedir” denilmiştir. Bu çerçevede TCK m.164 bakımından, gerçeğe aykırı şekilde hazırlanan ve finansal tablolar kapsamında bulunan şirket bilançosu, gelir tablosu, VUK m.359'da belirtilen “vergi kanunları uyarınca tutulan veya düzenlenen ve saklama ve ibraz mecburiyeti bulunan defter, kayıt ve belgeler ${ }^{147}$ " kapsamındadır. Şöyle ki;

Her ticari şirket, TTK m.64 uyarınca defter tutma yükümlülüğü altındadır. Bununla birlikte, söz konusu yükümlülüğün şeklen yerine getirilmesi yeterli değildir; tutulan defterler birtakım özelliklere sahip olmalıdır. Nitekim TTK m.64’e göre bu çerçevede tutulan defterlerin, “... tacirin ticari işlemleriyle ticari işletmesinin iktisadi ve mali durumunu, borç ve alacak ilişkilerini ve her hesap dönemi içinde elde edilen neticeleri, bu Kanuna göre açıkça görülebilir bir şekilde ortaya koyması" zorunludur. TTK m.64/5'te ise, "Bu Kanuna tabi gerçek ve tüzel kişiler, 4/1/1961 tarihli ve 213 sayıl Vergi Usul Kanununun defter tutma ve kayıt zamanıla ilgili hükümleri ile aynı Kanunun 175 inci ve mükerrer 257 nci maddelerinde yer alan yetkiye istinaden yapılan düzenlemelere uymak zorundadır. Bu Kanunun defter tutma, envanter, mali tabloların düzenlenmesi, aktifleştirme, karşılıklar, hesaplar, değerleme, saklama ve ibraz hükümleri 213 sayılı Kanun ile diğer vergi kanunlarının aynı hususları düzenleyen hükümlerinin uygulanmasına, vergi kanunlarına uygun olarak vergi matrahının tespit edilmesine ve buna yönelik mali tabloların hazırlanmasına engel teşkil etmez" denilerek, TTK uyarınca tutulan defter ve kayıtların VUK’a uygun olma zorunluluğuna açıkça işaret edilmiştir. Buna paralel olarak VUK m.175’te, "Mükellefler bu kısımda yazılı maksat ve esaslara uymak şartıyla, defterlerini ve muhasebelerini işlerinin bünyesine uygun olarak diledikleri usul ve tarzda tanzim etmekte serbesttirler (m.175/1), Ticaret Kanununun ticari defterler hakkındaki hükümleri mahfuzdur (m.175/2)" hükmüne yer verilmiştir.

145 Bayraktar ve diğer yazarlar, s. 420.

146 TCK’da, 765 sayılı eski kanundan farklı olarak maddi-fikri sahtecilik ayrımı yapılmadığı, gerçeğe aykırı belge düzenlemenin, kamu görevlisi tarafından işlenen resmi belgede sahtecilik suçunda seçimlik hareket olarak kabul edildiği hususunda bkz. GÖKCEN, Ahmet, Belgede Sahtecilik Suçları, 5. Baskı, Adalet, 2018, s. 312.

147 Yargitay 11. CD., 07.06.2001 tarih, 2001/5484 E., 2001/6522 K. sayılı ilamında, "kira kontratının 213 sayılı Kanunun 172. maddesinde gösterilen defterlerden ve 2. kitap 3. kısımda yazılı belgelerden olmadiğına” işaret etmiştir. 
VUK’un, "defter tutma" başlıklı ikinci kısmın, "bilanço esasına göre defter tutma" başlıklı üçüncü bölümünde yer alan 192 'nci maddesinde, bilançonun içeriği ve esaslarından ayrıca bahsedilmesi, bu görüşü destekler mahiyettedir.

Temel mali tabloları oluşturan gelir tablosu ve bilanço, vergiye esas teşkil eden belgelerdir.

$\mathrm{Bu}$ izahtan hareketle, söz konusu belge ve kayıtların sahte olması durumunda, VUK m.359/1-b'nin uygulanması $^{148}$ gerektiği ifade edilebilir ${ }^{149}$. Netice itibarılya failin, TCK m.164 ve VUK m.359/1b’den ayrı ayrı cezalandırılması gerekir.

Konuyla ilgili son olarak belirtmek gerekir ki VUK m.340/1'de yer verilen, "bu kanunda yazıl vergi ziyaı cezası ve usulsüzlük cezaları ile 359. maddede ve diğer kanunlarda yazılı cezalar; içtima ve tekerrür hükümleri bakımından birleştirilemez" hükmü uyarınca, oluşan vergi kayıpları dikkate alınarak, vergi ziyaı cezası kesilmesi de söz konusu olabilir.

\section{Sonuç}

TCK m.164’te düzenlenen şirket veya kooperatifler hakkında yanlış bilgi verme suçu, ekonomi ceza hukukunun çekirdek alanında yer almakta olup spesifik olarak ekonomik suçluluğun bir çeşidi olarak kabul edilen beyaz yaka suçluluğu kapsamında değerlendirilebilir. Nitekim kanun koyucu, şirket veya kooperatifler hakkında gerçeğe aykırı önemli bilgi verilmesini, herhangi bir netice aramaksızın suç olarak düzenleyerek madde gerekçesinde, suç tanımıyla, yalnızca şirket veya kooperatiflerin idaresinde güven ve iyi niyetin korunmasının amaçlandığına işaret etmiştir. Dolayısıyla, suçun ihdasıyla, kişilere ait mülkiyet haklarının korunduğunu söylemek zorlama bir yorumdur. Buradan hareketle suçun, mağduru belli olmayan bir suç olarak kabul edilmesi kaçınılmaz olup içtima bakımından zincirleme suç hükümlerinin uygulanmasında da bu husus dikkate alınmalıdır. Bu itibarla, bu suça, şirketler ve kooperatiflere ilişkin bütüncül yaklaşımı korumak adına TCK'da, "Ekonomi, Sanayi ve Ticarete Karşı İşlenen Suçlar" kapsamında yer verilmesi veyahut da suçun, Türk Ticaret Kanunu ve Kooperatifler Kanunu’nda ayrı hükümlerle düzenlenmesinin daha isabetli olacağı kanaatindeyiz.

Suçun oluşabilmesi için TCK m.164’te fail olarak sayılan kişilerin, kamuya yaptıkları beyanlarda veya genel kurula sundukları rapor ve önerilerde yer alan bilgilerin gerçeğe aykırı olması aranmıştır.

148 VUK m.359/1-b’ye göre cezanın belirlenmesinde, düzenlenen sahte belgelere dayanılarak oluşturulan beyannamelere göre belirlenen vergilerin hesap dönemleri esas tutularak, Vergi Denetim Kurulu Başkanlığınca yürütülecek inceleme sonucunda hazırlanacak rapordaki tespitlere göre, belgelerin kullanıldığı her bir hesap döneminin ayrı bir suç oluşturduğu dikkate alınmalıdır. Nitekim Yargitay Ceza Genel Kurulu’nun, 5.3.2002 tarih ve 2002/11-28 E., 2002/179 K. sayll ilamında; "213 sayılı Vergi Usul Yasasının 174. maddesinde vergi uygulaması bakımından mükelleflerin defter ve kayıt tutup kapatmalarına ilişkin olarak "hesap dönemine" yer verilmiş, madde de hesap dönemi bir takvim ytl olarak tanımlanmıştır. Kural olarak hesap dönemi 1 Ocak - 31 Aralı arası bir dönemi ifade etmektedir... Anılan Yasanın 4369 sayıl Yasa ile yürürlükten kaldırlan 358. maddesi ile halen yürürlükte bulunan usulsüzlük cezalarına ilişkin hükümlerinde, suçların oluşumu bakımından hesap dönemi-takvim yılının esas alındığı görülmektedir" denilerek her bir hesap döneminde kullanılacak sahte belgenin ayrı bir suça vücut vereceğine işaret edilmiştir.

149 TEZCAN, Durmuş/ERDEM, Mustafa Ruhan/ÖNOK, R. Murat, Teorik ve Pratik Ceza Özel Hukuku, 17. Baskı, Seçkin, Ankara, 2019, s.960. 
Şirket veya kooperatifin mevcut durumuyla bağdaşmayan her bilgi, gerçeğe aykırı olacaktır. Bilginin şirketin lehine yahut aleyhine olmasının, suçun oluşumuna etkisi yoktur. Bunun dışında, bilginin içeriğinin, ilgililerin malvarlığı değerini zarara uğratan yahut zarara uğratma tehlikesi yaratan bir mahiyette olması; suçun haksızlık içeriğini karşılayan bir öneme sahip bulunması da gereklidir. Sermayeye, yönetime ve ticari faaliyete ilişkin olup gerçeğe aykırı olan her bilginin bu önemi haiz olduğu söylenebilir. Bunun dışında kalan konulardaki bilgilerin önemi, her somut olaya göre belirlenmelidir.

Fail tarafından verilen gerçeğe aykııı bilginin şirket veya kooperatife ilişkin olması zorunludur. Madde kenar başlığında ve madde metninde "şirket" ibaresine yer verilmesi dolayısıyla, adi ortaklıkların bu kapsamda değerlendirilmesi mümkün değildir.

Şirket veya kooperatif hakkında yanlış kabul edilemeyecek eksik bilgi verilmesi yahut aydınlatma yükümüne aykırı olarak bilgi verilmemesi, TCK m.164 kapsamında değerlendirilemez. Çünkü maddede, gerçeğe aykırı bilgi verme veya verdirtme suç olarak kabul edilmiştir. Düşüncemize göre, şirketle ilgili bilgi verme yükümlülügü altında olan kişilerce eksik bilgi verilmesi veya hiç bilgi verilmemesinin de hükmün kapsamına alınması yerinde olacaktır. Nitekim mehaz İsviçre Ceza Kanunu m.152'de eksik bilgi verilmesi de bu suç yönünden tipik bir davranış olarak kabul edilmiştir.

Kamuya yönelik gerçeğe aykırı bilgi sunulması ve genel kurula sunulan bilginin türü ve niteliği bakımından, TTK ve SPKn'de yer alan düzenlemelerin nazarı itibara alınması gerekir.

Doktrin ve uygulamada farklı görüşler bulunmaktaysa da kanımızca, failin şirket veya kooperatife ilişkin verilen veya verdirtilen gerçeğe aykırı bilgi suçun konusu değil, soyut tipte tarif edilen fiile ilişkin bir özelliktir. TCK m.164'te, fail tarafından verilen veya verdirtilen bilginin hangi konuyu kapsadığı hususunda bir belirleme yapılmamıştır. Bununla birlikte, şirket veya kooperatifler hakkında verilen veya verdirtilen gerçeğe aykırı bilginin, ilgilileri malvarlı̆̆ı açısından zarara uğratabilecek bir öneme sahip olması gerektiğine ilişkin maddede yer verilen ifade, suçun konusuna ilişkin genel bir çerçeve ortaya koymaktadır. Dolayısıyla, bilginin şirket veya kooperatifler ile ilgili kapsadığı konu, böylece belirlenebilir.

TCK m.164'te düzenlenen suç tipi, ekonomik suçların genelinde müşahede edildiği üzere, özgü suç özelliği taşımaktadır. Bu kapsamda, maddede belirtilen sıfatları haiz olanların belirlenmesinde, Türk Ticaret Kanunu ve Kooperatifler Kanunu hükümleri çerçevesinde, şirket veya kooperatifin yönetim-organizasyona ilişkin yapısı nazarı itibara alınacaktır. Failin belirlenmesi ve iştirak hükümleri çerçevesinde ayrıca belirtmek gerekir ki tatbikatta, maddede sayılan kişiler, şirket yönetimiyle bağlantılı konular da dahil olmak üzere ticari hayatta, sıklıkla temsilcileri aracılı̆̆ıyla işlem yapmaktadırlar. Bu durumda, bazı ülkelerin ceza kanunlarında, söz konusu kişinin fail olarak sorumlu tutulmasına yönelik hükümler sevk edildiği görülmektedir. Mevzuatımızda bu yönde bir düzenleme bulunmadığından, TCK m.40 kapsamında bu kişilerin suçun faili olamayacakları, ancak yardım eden olarak işlenen suçtan sorumlu tutulacakları söylenmelidir. Özellikle bu gibi suçlarda, en azından maddeye bu kişilerin sorumluluğuna işaret edecek ifadeler eklemenin doğru olacağ kanaatindeyiz. 
Maddede düzenlenen seçimlik hareketler yönünden fail, gerçeğe aykırı önemli bilgiyi kendisi verebileceği gibi, örneğin şirkette çalışan bir başkasına da verdirtebilir. İsviçre hukukunda, İsviçre Ceza Kanunu m.29'da yer verilen özel düzenleme dolayısıyla, maddede sayılan kişilerden olmasa dahi şirket iradesinin oluşumunda belirleyici olan kişiler de (fiili organ) fail olarak kabul edilmiştir. Ticaret hukukunda, fiili organ teorisine göre maddi anlamda organ olarak kabul edilen kişilerin, hukukumuz açısından da fail olarak sorumlu tutulmasının mümkün olduğunu düşünmekteyiz.

Son olarak içtima bahsinde, gerçeğe aykırı bilgilerin yer aldığı belgelerin mahiyetine göre, TCK m.164’e göre tipik kabul edilen eylemlerin VUK m.359'a göre suç oluşturmasının mümkün olduğu görüşünde olduğumuza işaret etmeliyiz.

\section{KAYNAKÇA}

AKBULUT, Berrin, Ceza Hukuku Genel Hükümler, 6. Baskl, Adalet, Ankara, 2019.

AKDAĞ GÜNEY, Necla, Anonim Şirket Yönetim Kurulu, 2. Baskı, Vedat, İstanbul, 2016.

ARTUÇ, Mustafa, Malvarlı̆̆ına Karşı Suçlar, 4. Baskı, Adalet, Ankara, 2020.

ARTUK, Mehmet Emin/GÖKCEN, Ahmet/YENIDÜNYA, A. Caner, Ceza Hukuku Genel Hükümler, 10. Bask1, Adalet, Ankara, 2016.

ATALAY, Oğuz, Anonim Şirketlerde Bilgi Alma ve İnceleme Haklarının Mahkeme Aracılığılla Kullanılması, in: Prof. Dr. Hakan PEKCANITEZ’e Armağan (Dokuz Eylül Üniversitesi Hukuk Fakültesi Dergisi, C. 16, Özel Sayı 2014,) (s. 53-76).

AYGÖRMEZ, Gülsün Ayhan, Alman Ekonomi Ceza Hukukuna Giriş I, CHD, S.14, Aralık 2010, (s. 67-88).

AYTEKIN İNCEOĞLU, Asuman, Bankacllı Kanunu’nda Yer Alan Suçlar, Marmara Üniversitesi SBE, Yayımlanmamış Doktora Tezi, İstanbul, 2006.

BAYINDIR, Sinan/APIŞs, Özge, Bir Hukuka Uygunluk Nedeni Olarak Haber Verme Hakkının Yazılı Basın Yoluyla İşlenen Hakaret Suçları Açısından Değerlendirilmesi, Türkiye Barolar Birliği Dergisi, Y.2010, S.91, (s. 67-109).

BAYRAKTAR, Köksal/YILDIZ, Ali Kemal/AKSOY RETORNAZ, Eylem/AKYÜREK, Güçlï/EVİK, Ali Hakan/KANGAL, Zeynel T./MEMIŞ KARTAL, Pınar/SINAR, Hasan/SONAY EVIK, Vesile/ ALTUNÇ, Sinan/AYTEKIN İNCEOĞLU, Asuman/BOZBAYINDIR, Ali Emrah/ERMAN, Barış, Özel Ceza Hukuku (Malvarlığına Karşı Suçlar), Cilt IV, Onikilevha, İstanbul, 2018.

BECKER, Gary S., Crime and Punishment: An Economic Approach, Journal of Political Economy, Mar. - Apr., 1968, Vol. 76, No. 2, (s. 169-217)

BENSON, Michael L./SIMPSON, Sally S., White Collar Crime: An Opportunity Perspective, Taylor \& Francis Books, 2009.

BRENNER, Beat, Strafanzeige gegen Organe der SAirGroup Artikel 152 und 158 StGB im Visier, Recht im Spiegel der NZZ, Nr.2, 2001.

BRETTEL, Hauke/SCHNEIDER, Hendrick, Wirtschaftsstrafrecht, 3. Auflage, Nomos, Baden-Baden, 2021.

BUFFORD, Samuel, International Rule of Law and the Market Economy - An Outline, Southwestern Journal of Law \& Trade in The Americas, 2006.

CANPOLAT, Can, Ceza Muhakemesi Hukukunun Amaci: "Objektif gerçeğin keşfi mi? Yargısal (kazai) bir gerçeklik inşa etmek mi?”, Erciyes Üniversitesi Hukuk Fakültesi Dergisi, C.15, S.2. 
CANPOLAT, Can, Uygulamaya Bakan Yönleriyle İşlem Temelli Piyasa Dolandırıcılığı (Manipülasyon) Suçu, in: 5. Türk-Kore Ceza Hukuku Günleri, Karşılaştırmalı Hukukta Ekonomik Suçlar Uluslararası Sempozyumu, Tebliğler, C.I, Seçkin, Ankara, 2020.

CEVİZCI, Ahmet, Felsefe Sözlüğü, 7. Baskı, Paradigma Yayıncılık, İstanbul, 2010.

CİN ŞENSOY, Şehnaz, “Ekonomik Suç Kavramı ve Ekonomik Suçların Kriminolojik Özellikleri”, Prof. Dr. Çetin Özek Armağanı, Galatasaray Üniversitesi Yayınları:32, İstanbul, 2004.

DONATSCH, Andreas, Art. 152 Unwahre Angaben über kaufmännische Gewerbe, in StGB/JStG Kommentar, 20. Überarbeitete Auflage, Orell Füssli Verlag, 2018.

DONATSCH, Andreas, Buchführung und Strafrecht Steuerstrafrecht im Zentrum, ST 3/04 (Der Schweizer Treuhänder), (s. 201-206).

DÖNMEZER, Sulhi, Basın Hukuku Cilt: 1, Sulhi Garan Matbaası, İstanbul, 1958.

DÖNMEZER, Sulhi, Kriminoloji, Gözden Geçirilmiş 8. Bası, İstanbul, Beta, 1994.

DUMAN, Haluk, Sermaye Piyasasının Etkinliği Açısından, Kamunun Aydınlatılması Sürecinde, Şirket Çevresinin İhtiyaç Duyduğu Bilginin Özellikleri: İMKB’de Bir Uygulama, Muhasebe ve Finansman Dergisi, Nisan 2011, (s. 95-132).

DURSUN, Gizem, "Ekonomik Suça Ekonomik Ceza İlkesi” ve Bu Kapsamda 6362 Sayılı Sermaye Piyasası Kanunu'nda Bilgi Suistimali ve Piyasa Dolandırıcılığı Suçları İçin Öngörülen Cezaların Değerlendirilmesi, Bahçeşehir Üniversitesi Hukuk Fakültesi Dergisi, C.14, S.175-176, (s. 853-885).

DURSUN, Selman, Ekonomik Suçlar ve Bankacılık Suçları Bağlamında Bankacılık Düzenine Karşı İşlenen Suçlar, Seçkin, Ankara, 2005.

DURSUN, Selman, Sermaye Piyasasında Gerçeğe Aykırılıktan Doğan Suçlar, Oniki Levha, İstanbul 2010.

ERMAN, Sahir, Ticari Ceza Hukuku, C.1, Genel Kısım, 3. Bası, İstanbul, 1992.

EVIK, Ali Hakan, Sermaye Piyasası Kanununda Düzenlenen Güveni Kötüye Kullanma ve Sahtecilik Suçları II, Ceza Hukuku Dergisi, S.42, Nisan 2020, (s.43-84).

FORSTMOSER, Peter, Der Organbegriff im aktienrechtlichen Verantwortlichkeitsrecht, in: Forstmoser/ Schluep (Hrsg.), Freiheit und Verantwortung im Recht, Festschrift zum 60. Geburtstag von Arthur Meier-Hayoz (Bern 1982), (s. 125-150).

GÖKCEN, Ahmet, Belgede Sahtecilik Suçları, 5. Baskı, Adalet, Ankara 2018.

GRAY, Richard L., Eliminating the (Absurd) Distinction Between Malum In Se and Malum Prohibitum Crimes, Washington University Law Review, Volume 73, Issue 3, 1995 (Northwestern University/Washington University Law and Linguistics Conference), (s.1369-1398).

GREEN, Stuart P., The Concept of White Collar Crime in Law and Legal Theory, Buffalo Law Rewiev, Vol. 8:1.

GÜNER, Uğur, Ekonomik Suçlar ve Ekonomi Ceza Hukukuna İlişkin Yasal Düzenlemeler, Dokuz Eylül Üniversitesi Hukuk Fakültesi Dergisi, Prof. Dr. Durmuş TEZCAN’a Armağan, C.21, Özel Sayı, 2019, (s. 1411-1442).

HANSLIN, Marc, Markt - und Kursmanipulation Art. 143 und Art. 155 FinfraG sowie Art. 122 ff. FinfraV, Dike Verlag, 2017.

JECKER, Marc Jan, Die konkurs - und strafrechtliche Aufarbeitung der Kriminalinsolvenz, Dike Verlag, 2009.

JUTZI, Thomas, Unternehmenspublizität Grundlinien einer rechtlichen Dogmatik zur Offenlegung von unternehmensbezogenen Informationen, Stämpfli Verlag, 2017.

KISSLING, Mischa, Der Mehrfachverwaltungsrat(DieTätigkeitin Verwaltungsräten mehrerer Aktiengesellschaften aus Sicht des Zivil-, Straf-, Wettbewerbs-, Steuer - und Sozialversicherungsrechts, Schultess, 2007.

KOCA, Mahmut/ÜZÜLMEZ, İlhan, Türk Ceza Hukuku Genel Hükümler, 11. Baskı, Seçkin, Ankara, 2018. 
KÜÇÜKTAŞDEMİR, Özgür, Ekonomik Suçlar Bağlamında Türk Ticaret Kanununda Düzenlenen Suçlar ve Cezalar, Seçkin, Ankara, 2018.

LANZ, Martin/RYSER, Roland M., Strafrechtliche Aspekte der Ad-hoc-Publizität Inwiefern sind Verstösse gegen Art. 72 KR-SWX nach Art. 152 StGB strafbar?, SZW 2008, (s. 26-36).

LEHMANN, Peter, Die "kleine Aktienrechtsrevision" (Teil 2) - Neuerungen in den Bereichen Aktionärsrechte, Firma, Handelsregister, GesKR 2007, (s. 420-428).

MAHMUTOĞLU, Fatih Selami, Ekonomik Suçlar Bağlamında Kredi Hukukundan Kaynaklanan Suç ve İdari Suçlar, Seçkin, Ankara, 2003.

MEIER, Bernd Dieter, Kriminologie, 5. Auflage, C.H Beck, München, 2016.

ÖZBEK, Veli Özer/BACAKSIZ, Pınar/DOĞAN, Koray/TEPE, İlker, Türk Ceza Hukuku Genel Hükümler, 9. Baskı, Seçkin, Ankara, 2018.

ÖZBEK, Veli Özer, Ekonomi Ceza Hukuku, Seçkin, Ankara, 2020.

ÖZGENÇ, İzzet, Türk Ceza Hukuku Genel Hükümler, 14. Bası, Seçkin, Ankara, 2018.

ÖZTÜRK, Bahri/ERDEM, Mustafa Ruhan, Uygulamalı Ceza Hukuku ve Güvenlik Tedbirleri Hukuku, Seçkin, Ankara, 2018.

SCHALLER, Jean Marc, Finanzanalysten-Recht Die Berufstätigkeit der Finanzanalysten im Rahmen des Privat, Straf - und Aufsichtsrechts, Schultess, 2004.

SCHLEGEL, Stephan, Art. 152 StGB, in: Wolfgang Wohlers, Gunhild Godenzi, Stephan Schlegel, Schweizerisches Strafgesetzbuch Handkommentar, 4. Auflage, Stämpfli Verlag AG, 2020.

SCHLEIFFER, Patrick/REINWALD, Urs, Management-Transaktionen: Rechtsgrundlagen, Umsetzung und

SCHMID, Niklaus, Titel Das neue Vermögens - und Urkundenstrafrecht, SJZ 91/1995, (s. 1-11).

SHOVER, Neal, Generative Worlds of White-Collar Crime in: International Handbook of White-Collar and Corporate Crime, (Editors:Henry N. PONTELL, Gilbert GEIS), Springer, 2007.

SHOVER, Neal/HOCHSTETLER, Andy, Choosing White-Collar Crime, Cambridge University Press, 2006

STRADER, J.Kelly, Understanding White Collar Crime, Matthew Bender \& Company Inc., 2002.

TEZCAN, Durmuș/ERDEM, Mustafa Ruhan/ÖNOK, R. Murat, Teorik ve Pratik Ceza Özel Hukuku, 17. Baskı, Seçkin, Ankara, 2019.

TIEDEMANN, Klaus/ENGELHART, Marc, Wirtschaftsstrafrecht, 5. Auflage, Vahlen, 2017.

TOPUZ, VEYSEL, Sermaye Piyasası Suçlarında Yazılı Başvuru Şartı ve Görevli ve Yetkili Mahkeme, İnönü Üniversitesi Hukuk Fakültesi Dergisi, S.10/1, 2019, (s. 159-172).

TRECHSEL, Stefan/CRAMERI, Dean, Art. 152 StGB, in: Schweizerisches Strafgesetzbuch Praxiskommentar, 3. Auflage, Die Verlag, 2018.

URAN, Peri, Avrupa İnsan Hakları Mahkemesi ve Türk Anayasa Mahkemesi'nin Basın Özgürlüğüne Yaklaşımı, Türkiye Barolar Birliği Dergisi, Y.105, S.120, (s. 87-130).

WEBER, Rolf H./BAUMANN, Simone, Neukonzeption der Rechtsprechungsordnung im Börsenwesen, Schweizer Schriften zum Finanzmarktrecht Band/Nr. 103, 2012, (s. 80-95).

WEISSENBERGER, Philippe, Art. 152 StGB, in: Basler Kommentar, Strafrecht II, Art. 111-392 StGB, 2. Auflage, Basel, 2007.

WITTIG, Petra, Wirtschaftsstrafrecht, 5. Auflage, C.H Beck, München, 2020.

WONG, Kam C, From White-Collar Crime to Organizational Crime: An Intellectual History, Murdoch University eLaw Journal (çevrimiçi: http://www.austlii.edu.au/au/journals/MurUEJL/2005/14.html, erişim tarihi: 12.03 .2019 ) 